\title{
33. PYROLYTIC CHARACTER OF ORGANIC MATTER IN CENOZOIC SEDIMENTS ON THE OMAN SHELF 1
}

\author{
Kay-Christian Emeis ${ }^{2,3}$ and Jean K. Whelan ${ }^{2}$
}

\begin{abstract}
Analysis of the molecular composition and quantity of pyrolytic hydrocarbons in 41 samples from Owen Ridge and the Oman margin enabled us to identify chemical differences in the organic matter from Owen Ridge and the Oman margin. The differences may be attributed to regional variability in organic matter composition between margin and ridge, effects of kerogen formation and condensation with age, and effects of changes in the depositional environment on the Oman margin. Pyrolytic hydrocarbons from ridge sediments are relatively more enriched in heterocompounds, aromatic molecules, and $n$-alkanes and $n$-monoalkenes in the range $n-\mathrm{C}_{9}$ to $n$ - $\mathrm{C}_{14}$ when compared to margin sediments. This may be indicative of input of degraded organic material on Owen Ridge and less degraded material on the Oman margin. Increases of long-chain $n$-alkanes and $n$-monoalkenes with depth in sediments from the Oman margin are a result of the concentration of precursor moieties in the kerogen during low-temperature diagenesis. Differences in the depositional environment during deposition of sediments on the Oman margin (changes in the oxygen content of bottom waters and changing benthic activity in a variable oxygen minimum zone) appear to be mirrored in the distribution of monounsaturated isoprenoid hydrocarbons prist-1-ene and prist-2-ene and alkylbenzene.
\end{abstract}

\section{BACKGROUND AND OBJECTIVES}

We examine here chemical differences in organic matter from sediments deposited underneath the monsoonal upwelling system of the northwestern Arabian Sea by pyrolysis and pyrolysisgas-chromatography/mass spectroscopy. Our first objective was to find molecular criteria that would allow us to distinguish organic matter deposited under anaerobic conditions on the Oman margin, which are laminated, from sediments that are bioturbated and indicate aerobic bottom water conditions. Sediments from the Oman shelf and upper slope are uniquely suited to address the question of differences in organic matter preservation (e.g., Demaison and Moore, 1980; Henrichs and Reeburgh, 1987), because sections recovered at Site 723 on the Oman continental margin (Prell, Niitsuma, et al., 1989) appear to have been deposited under oxic and dysoxic to anoxic conditions in an oxygen minimum zone that changed intensity and/or depth range in the geological past. Analyzing the organic matter composition in sediment intervals deposited under aerobic (bioturbated facies) or anaerobic (laminated facies) conditions may thus provide insight into organic matter composition and rates of decay of compound classes as functions of aerobic and anaerobic bacterial metabolism. We can further calibrate our results using recent surface sediments, for which oxygen levels are known. A second objective was to test whether organic matter character is uniform on the shelf, i.e., underneath the most productive coastal upwelling centers, and the distal Owen Ridge, which has lower accumulation rates of organic carbon and where sedimentation may be strongly influenced by lateral transport from the Oman margin and eolian input.

\section{Study Area}

The wind-driven upwelling system of the northwestern Arabian Sea is characterized by seasonal variations in current direc-

\footnotetext{
${ }^{1}$ Prell, w. L., Niitsuma, N., et al., 1991. Proc. ODP, Sci. Results, 117: College Station, TX (Ocean Drilling Program).

${ }^{2}$ Chemistry Department, Woods Hole Oceanographic Institution, Woods Hole, MA 02543 , U.S.A.

${ }^{3}$ Current address: Geologisch-Paläontologisches Institut, Olshausenstraße 40,2300 Kiel, Federal Republic of Germany.
}

tion, upwelling intensity, and such biologically important properties of the surface waters as temperature, nutrient content, and primary productivity. Scant productivity data (Wyrtki, 1973) show that upwelling-related productivity during the summer monsoon may exceed $0.5 \mathrm{~g} \mathrm{C} / \mathrm{m}^{2} /$ day. The combination of high primary production, oxygen consumption, and a lack of advection of oxygenated waters creates a zone of greatly decreased oxygen content that ranges from approximately 150 to $1200 \mathrm{~m}$ water depth (Wyrtki, 1973). While the present oxygen levels in the core of the OMZ are sufficient to support benthic activity (D. Anderson, pers. comm. 1989), some Pleistocene and upper Pliocene sediments show laminations that suggest dysaerobic $\left(<0.3 \mathrm{~mL} / \mathrm{L} \mathrm{O}_{2}\right.$; Rhoads and Morse, 1971) and possibly anaerobic conditions in the past.

Site $723\left(18^{\circ} 03.079^{\prime} \mathrm{N}\right.$ and $57^{\circ} 36.561^{\prime} \mathrm{E}$; Fig. 1) was drilled in water $808 \mathrm{~m}$ deep and recovered uppermost Pliocene to Holo-

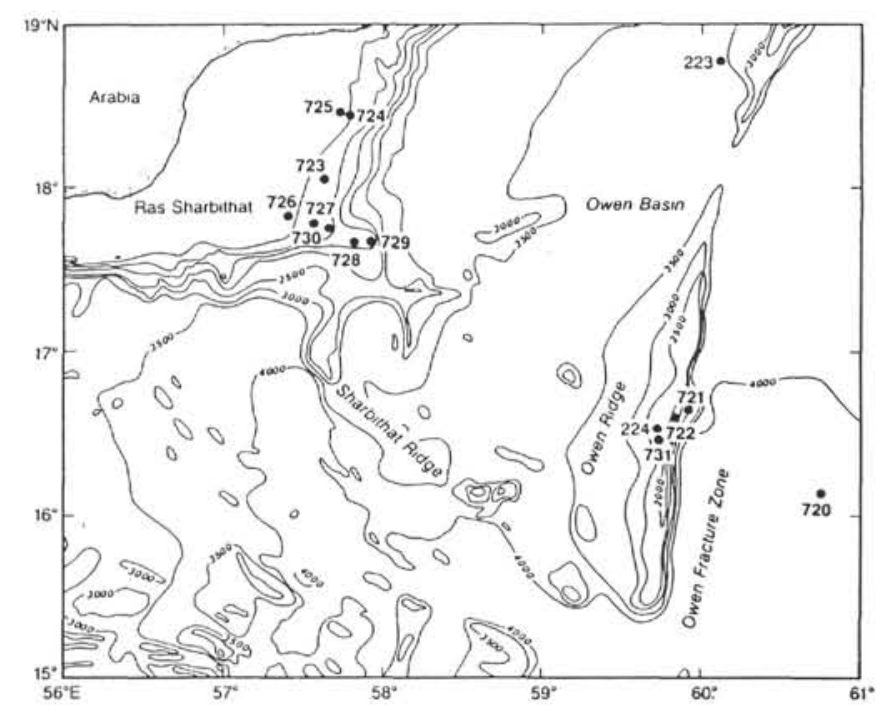

Figure 1. Location map of sites occupied during ODP Leg 117. 
cene(?) foraminifer-bearing nannofossil oozes to calcareous clayey silts. The sedimentation rate is high throughout the section (between 130 and $240 \mathrm{~m} / \mathrm{m} . \mathrm{y}$.) and the record of variability in eolian and biogenic input during the depositional period is very detailed (Prell, Niitsuma, et al., 1989). Abundance of TOC and the occurrence of laminations in intervals of latest Pliocene to early Pleistocene suggest that bottom-water oxygen contents were lower and precluded bioturbation. Eighteen samples from Hole 723A were used; their depth ranges from 5.9 to $410 \mathrm{mbsf}$.

Site $728\left(17^{\circ} 40.790^{\prime} \mathrm{N}\right.$ and $\left.57^{\circ} 49.553^{\prime} \mathrm{E}\right)$ is located in water $1430 \mathrm{~m}$ deep at the lower boundary of the present-day OMZ on the Oman margin (Fig. 1). The recovered section ranges from late Miocene to Holocene in age and sediments are similar in facies than those at Site 723 , even though sedimentation rates are significantly lower than at Site $723(11-90 \mathrm{~m} / \mathrm{m}$.y.). Seven samples from this site were analyzed; their depth ranges from 21.4 to 198.8 mbsf.

Surface sediment samples were obtained from box cores retrieved during the 1987 cruise 27 of Robert Conrad (Mountain and Prell, 1989) and span the depth interval of the present-day oxygen minimum zone. Bottom-water samples overlying cores RC2714 (590 m water depth), RC2712 (788 m) and RC2723 (815 $\mathrm{m})$, and RC2709 $(891 \mathrm{~m})$ had oxygen concentrations of 0.25 $\mathrm{mL} / \mathrm{L}$. Carbonate and TOC concentrations of these cores were between $40 \%$ and $50 \%$, and $4 \%$ to $8 \%$, respectively. Surface sediment from core $\mathrm{RC} 2724(1400 \mathrm{~m})$ contained $64 \% \mathrm{CaCO}_{3}$ and $2.7 \%$ TOC, and bottom-water oxygen was measured at 1.0 $\mathrm{mL} / \mathrm{L}$ (D. Anderson, pers. comm., 1988).

Site 722 is located on Owen Ridge $\left(16^{\circ} 37.312^{\prime} \mathrm{N}\right.$ and $59^{\circ} 47.755^{\prime} \mathrm{E}$ ) in water $2030 \mathrm{~m}$ deep (Fig. 1). The oldest sediments are early Miocene silty claystones, but the dominant lithology is nannofossil ooze to diatomaceous nannofossil ooze with lighter and darker colored alternations on a scale of meters. Coincident with dark colors are TOC concentrations > $2 \%$ by weight, and a decrease in $\mathrm{CaCO}_{3}$. Sedimentation rates at Site 722 were between 17 and $54 \mathrm{~m} / \mathrm{m}$.y. We studied organic matter character and content in 11 samples spaced across two of the cyclic light-dark intervals in Cores 722A-16X (146-147 mbsf) and 722B-29X (270-271 mbsf).

\section{METHODS}

Characterization of organic matter in sediments is made difficult by the fact that condensation reactions during diagenesis lead to the formation of protokerogen and kerogen, which are difficult to study on the molecular level (e.g., Durand, 1980). However, studies of thermally immature and mature sediments have shown that the methods of pyrolysis (in conjunction with gas chromatography/mass spectroscopy) are well suited for the study of these condensed products, which make up more than $80 \%$ of sedimentary organic matter (e.g., Durand, 1980). The method of pyrolysis-gas chromatography/mass spectroscopy employed in this study has been used in a number of laboratories mainly in the assessment of hydrocarbon source rocks, but also for differentiating between kerogen types and organic matter characteristics. An overview of the literature on this method is given in Barker and Wang (1988). The pyrolytic approach to compositional discrimination between degraded and undegraded organic matter has been used previously to distinguish aerobic from anaerobic conditions in black shales (Pratt et al., 1986) and in upwelling sediments (Emeis and Morse, 1990; Emeis et al., in press).

The method used in this study is described in detail in Whelan et al. (1990) and Tarafa et al. (1987): 10-30 mg of freezedried and ground sediment (after core splitting on JOIDES Resolution) is placed in the cooled interface of a Chemical Data Systems (CDS) Model 820 Geological Reaction System and heated at $30^{\circ} \mathrm{C} / \mathrm{min}$. from $200^{\circ}$ to $600^{\circ} \mathrm{C}$. Organic compounds desorbed and pyrolyzed during the heating process are swept out of the system in a helium stream. The stream is split three ways: one part goes directly to a flame ionization detector (FID), a second split is trapped for gas chromatography (GC), and a third part is used to characterize the molecular composition of pyrolysates with a GC-mass spectrometer. This experimental setup yields information on molecular composition in addition to the well-known hydrogen indexes (given in $\mathrm{mg}$ of pyrolysate/g of TOC). Calibration of GC-amenable components in the pyrolysates is achieved by direct injection of a standard mixture of known composition (toluene, xylenes, and $n$-alkanes from octane to octadecane). The results on compositions and amounts of individual components of pyrolysates are generally highly reproducible; precisions of $\pm 10 \%$ are routinely obtained on resolved capillary GC peaks.

Although catalytic effects at low TOC (below 2 wt \%) influence the results of Rock-Eval pyrolysis (e.g., Katz, 1983), we found that catalytic artifacts did not systematically alter the composition of pyrolysates in experiments with bulk sediment and extracted kerogen. A set of five samples (listed in Table 1) was analyzed as bulk sediment and after kerogen preparation. A plot comparing average values of yields from bulk sediment and kerogen shows that the abundances differ after extraction of kerogen, but that the overall distribution patterns are not significantly different (Fig. 2).

Organic carbon (TOC) concentrations were obtained after combustion of acidified samples under helium in a Coulometrics $\mathrm{CO}_{2}$ Analyzer, and pyrolysis yields were calculated as $\mathrm{mg}$ hydrocarbons per $\mathrm{g}$ of TOC, the Hydrogen Index (HI). Individual molecular compounds are reported by weight (in ng of thermally evolved compound/mg TOC in GC runs) as detected with a flame-ionization detector.

The total number of peaks (and compounds) in each gas chromatogram is beyond the number of parameters that can reasonably be monitored and compared between samples without the aid of automated data collection and reduction via computer. We selected and quantified 32 compounds in the gas chromatogram of each sample. They encompass the dominant contributors to the resolved pyrolysates (skewed toward hydrocarbons, which are the dominant compounds) and were further selected to include examples of each major compound class present in the pyrolysate (Fig. 3). The sum of these $32 \mathrm{com}$ pounds is between $17 \%$ and $39 \%$ of the resolved pyrolysis yield in the samples studied here. The data matrix was used as input for multivariate data analysis (factor analysis and VARIMAX rotation) with the SYSTAT package on an Apple Macintosh.

\section{RESULTS AND DISCUSSION}

Four kerogen preparations of samples from Hole 723A and a kerogen of organic-lean marl (TOC $<0.1 \%$ ) from Hole $722 \mathrm{~A}$ were examined by fluorescent and reflected-light microscopy (D. I. O'Connor, pers. comm., 1989; Table 1). All samples from Site 723 had very similar kerogen characteristics, and organic matter was dominantly composed of marine macerals, i.e.. amorphous and exinitic matter, which together accounted for more than $90 \%$ of the particles. Land-derived material, i.e., vitrinite, was less than $10 \%$. Inertinitic, or residual charcoal-like material, accounted for less than $5 \%$ in the samples. The one sample of organic-lean marl from Site 722 contained very little kerogen, as is typical for deep-sea sediments deposited under oxic bottom-water conditions, and vitrinite and inertinite are relatively more abundant than in the margin samples. They constitute residual, reworked organic matter, and possibly a higher contribution by wind-blown terrigenous particles.

In the light of the dominantly marine organic matter in sediments from margin and ridge, the yield of pyrolyzable hydrocarbons per $\mathrm{g}$ of TOC (the hydrogen index, HI) of both margin 


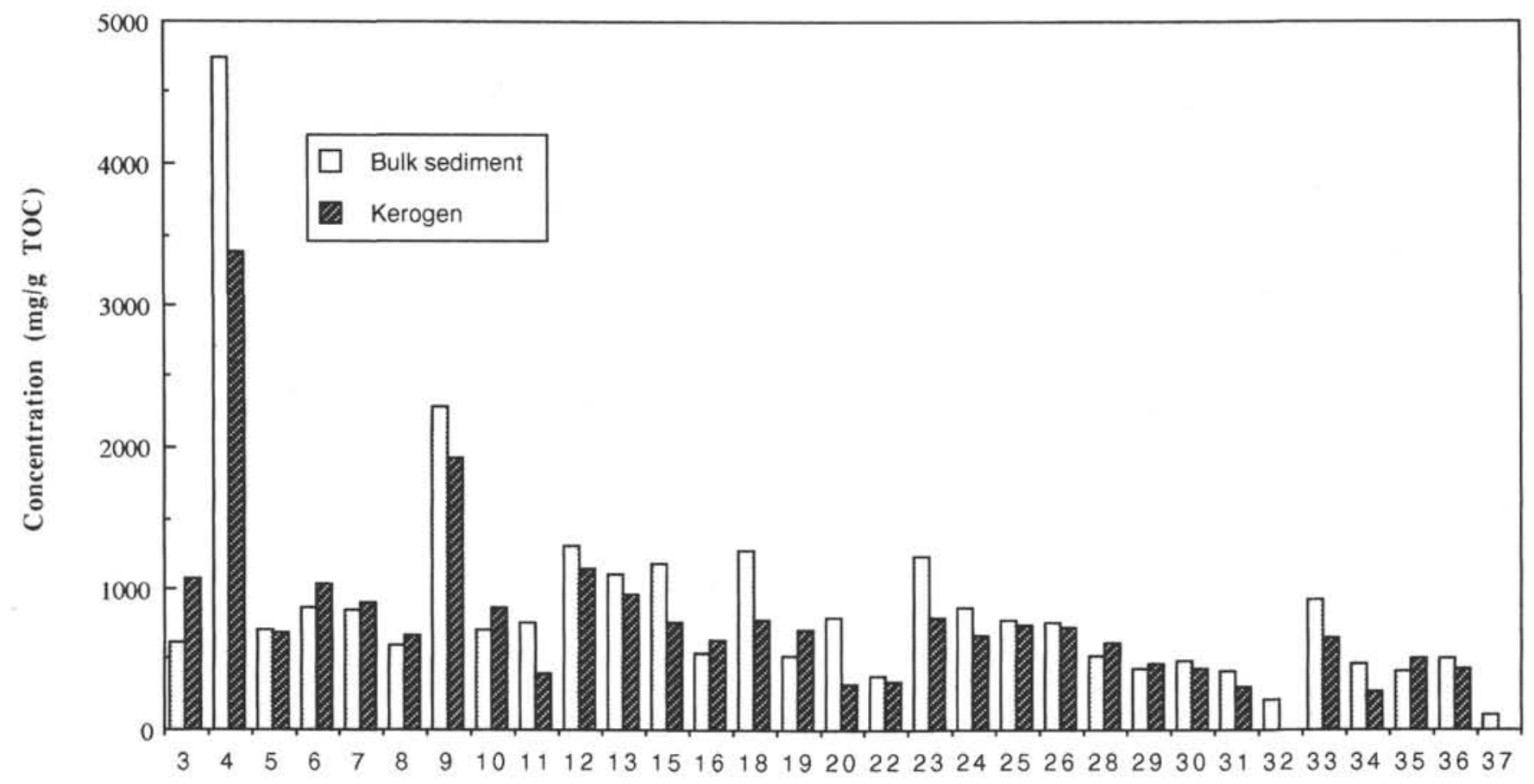

\section{Compound Number}

Figure 2. Plot of average yields of pyrolytic hydrocarbons for five bulk samples and corresponding kerogens. Numbers on X-axis are keyed to compounds from Table 3 . Note that the abundances may change due to the chemical preparation of kerogens, but that the compositional patterns are the same.

and ridge samples was thus expected to follow the line of marine type II organic matter (Espitalié et al., 1977). Figure 4 is a representation of oxygen and hydrogen indexes of the samples from Oman margin Sites 722, 723, and 728 studied onboard the JOIDES Resolution (Prell, Niitsuma, et al., 1989). The oxygen and hydrogen indexes of samples from Sites 723 and 728 plot between the evolution path of marine type II and terrestrial type III organic matter. The shift toward more oxygen-rich type III may be attributable to the presence of oxygen-rich organic matter and possibly to thermal decomposition of carbonate minerals in these immature and carbonate-rich sediments. Even though we cannot rule out that mineral matrix effects, e.g., contribution of $\mathrm{CO}_{2}$ from pyrolytic carbonate decarboxylation, contribute to the elevated OI of the samples from the Owen Ridge, we take the significantly higher OI in these samples as an indication of different composition of organic matter. For this we have two reasons: the sediments of the Oman margin (Site 723) contain roughly the same amount and compositional assemblage of siliciclastic material as does the Owen Ridge sediment, and $\mathrm{CaCO}_{3}$ concentrations in excess of $50 \%$ on the margin vs. $60 \%-70 \%$ on Owen Ridge cannot explain the significant differences in pyrolytic $\mathrm{CO}_{2}$ yield from mineral decomposition.

\section{Molecular Composition of Pyrolysates}

If different depositional conditions indeed influence the preservation of labile components of organic matter, as was proposed by Demaison and Moore (1980), we would expect to find a difference in the character and amounts of compounds that are released from sediments of different facies during pyrolysis. We should thus be able to identify indicators for preservation and different sources of organic matter in the pyrolysate.

Figure 3 shows a typical example of a reconstructed ion chromatogram of the total pyrolysate of Sample $723 \mathrm{~A}-1 \mathrm{H}-4,145-$
$150 \mathrm{~cm}$ (5.9 mbsf), obtained from gas-chromatography/mass spectrometry of pyrolysis products. Comparison of mass spectra of each peak with library spectra and with spectra of standards enables us to determine the molecular nature of these peaks. Once identified, the abundance of selected molecules (numbers keyed to Table 2) can be quantified on GC traces of all samples.

One prominent feature of the pyrolytic hydrocarbon fraction of all samples studied are the doublets of alkanes and alk-1-enes that extend from carbon chains of 8 carbon atoms to well beyond 20 carbon atoms. In every type II kerogen, these straightchain alkyl molecules appear to be important contributors to the pyrolysis products. Although their origin is not clear, they are thought to have a significant lipid contribution and to be precursor molecules in kerogen that yield hydrocarbons in petroleum during catagenesis (e.g., van de Meent et al., 1980). Nip et al. (1986) proposed that the precursors of alkane-alkene doublets are nonsaponifyable, highly resistant biopolymers that are very stable under any depositional conditions. They are believed to be highly aliphatic macromolecules with long polyalkyl (polymethylene) chains as major structural elements (Tegelaar et al., 1989). In addition to the normal alkanes and alkenes, we recognize substantial contributions of branched, aromatic, cyclic, and heterocompounds (containing $\mathrm{O}, \mathrm{N}$, and $\mathrm{S}$ ) in the pyrolysates. Polyunsaturated alkyl hydrocarbons were not observed in the pyrolysates.

\section{Statistical Evaluation of Molecular Character}

The data matrix of 32 parameters from 41 samples was treated by statistical factor analysis (Table 3 ). We thus singled out those parameters that contribute most to the variance in the data and were able to compute factors (composites of parameters) that enable us to discriminate between samples (Howarth 


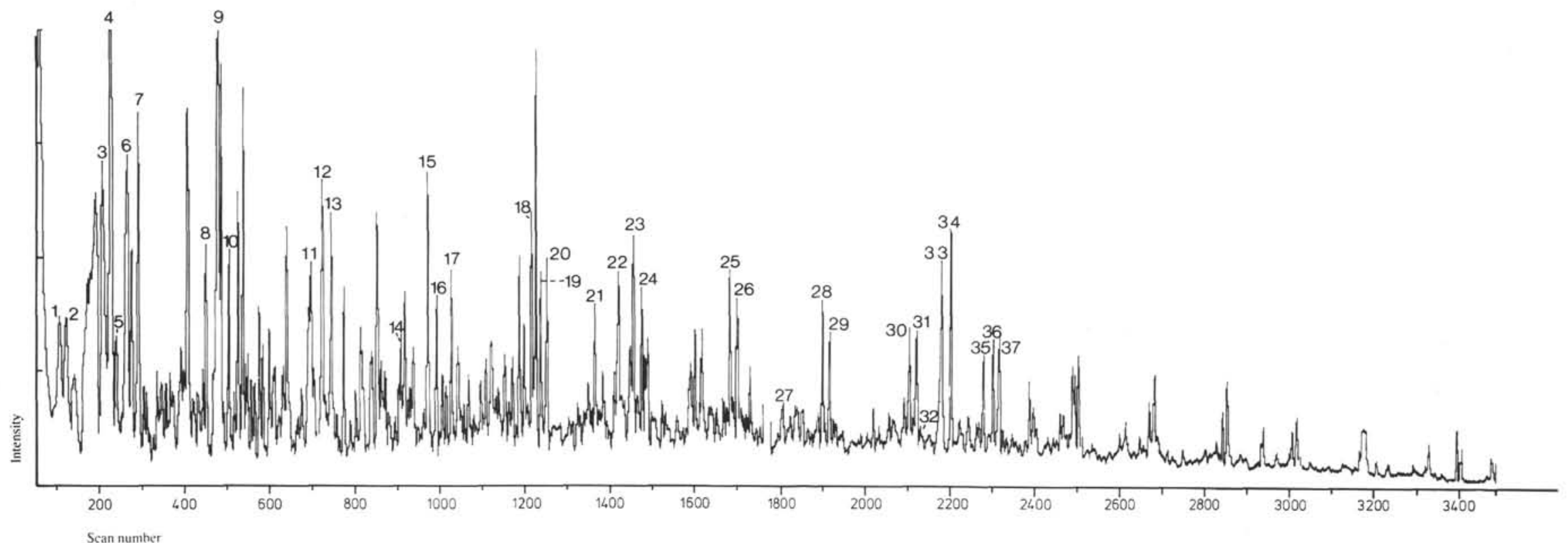

Figure 3. Reconstructed ion chromatogram of pyrolyzed organic compounds from Sample 723A-1H-4, $145-150 \mathrm{~cm}$ ( 5.9 mbsf). Examples of the most abundant compounds recognized from mass spectra are indicated. Quantification of compounds labelled 1 through 37 and listed in Table 3 was performed by gas chromatography. 
Table 1. Petrography of kerogen concentrates from Sites $\mathbf{7 2 3}$ and $\mathbf{7 2 2 .}$

\begin{tabular}{|c|c|c|c|c|c|c|}
\hline Sample & Description & Amorphous & Exinite & $\begin{array}{l}\text { Kerogen type } \\
\text { Vitrinite }\end{array}$ & Inertinite & Bituminite \\
\hline $723 \mathrm{~A}-1 \mathrm{H}-4,145-150 \mathrm{~cm}$ & $\begin{array}{l}\text { Light golden brown, fluffy amor- } \\
\text { phous algal material. Exinite } \\
\text { and vitrinite fragments } \\
\text { present, but oxidized and } \\
\text { rough. }\end{array}$ & 80 & 10 & 5 & 5 & 0 \\
\hline $723 \mathrm{~A}-9 \mathrm{H}-4,145-150 \mathrm{~cm}$ & As above & 80 & 10 & $\operatorname{Tr}$ & 5 & $5(?)$ \\
\hline $723 \mathrm{~A}-13 \mathrm{X}-4,145-150 \mathrm{~cm}$ & As above & 90 & 10 & $\operatorname{Tr}$ & $\operatorname{Tr}$ & 0 \\
\hline $723 \mathrm{~A}-29 \mathrm{X}-6,145-150 \mathrm{~cm}$ & As above & 90 & 10 & 0 & $\operatorname{Tr}$ & 0 \\
\hline $722 \mathrm{~A}-22 \mathrm{X}-4,145-150 \mathrm{~cm}$ & As above, relatively more inertinite & 60 & 10 & 15 & 15 & 0 \\
\hline
\end{tabular}

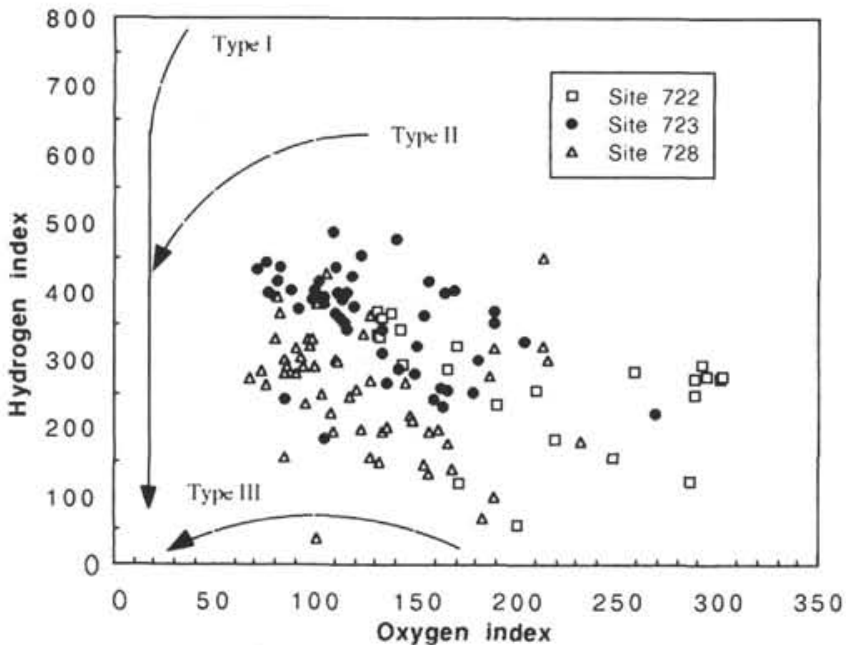

Figure 4. Plot of Hydrogen Index and Oxygen Index for samples from Sites 722, 723, and 728. Curved lines represent empirical compositions of type I (brackish) type II (marine) and type III (terrestrial) organic matter. Data from Prell, Niitsuma, et al. (1989).

and Sinding-Larsen, 1983). A similar approach has been used with good success by Øygard et al. (1988) on pyrolysates of kerogen samples from wells on the continental shelf of Norway. The result of the first step, the evaluation of parameters for their contribution to the variance in the entire data set, revealed that three factors contribute $80 \%$ to the variance, with factor 1 the most dominant contributor $(43 \%$ of variance after rotation). Factor 1 is predominantly loaded with contributions from aromatic and heteromolecules (naphthalenes, thiophenes), and from short-chain hydrocarbons (9-15 carbon atoms). Factor 2 ( $25 \%$ of the variance) is dominated by straight-chain saturated and monounsaturated hydrocarbons (16-18 carbon atoms) and isoprenoids pristane and phytane. Factor $3(11 \%$ of the variance) is dominated by alkylbenzene, and monounsaturated isoprenoids prist-1-ene and prist-2-ene (Table 2).

If we plot the scores of all samples on factors 1 and 2, we achieve a separation of samples from the Owen Ridge (Site 722) and samples from the margin (Fig. 5, top). The separation between samples from the margin and the ridge is mainly based on scores of samples on factor 1 (dominated by short hydrocarbon chains, heterocompounds, and aromatic molecules). Pyrolysates of sediments from the ridge is thus richer in these molecules per $\mathrm{g}$ of TOC than kerogen on the margin. On the other hand, samples from surface cores have the most negative scores on factor 1, which means that short-chain, aromatic, and heterocompounds are least abundant in organic matter from surface sediments on the Oman margin.
Table 2. List of compounds quantified in the pyrolysates and shown as numbers on Figure 3. Factor loadings for factors 1 to 3 are added.

\begin{tabular}{|c|c|c|c|c|}
\hline $\begin{array}{l}\text { Peak number } \\
\text { in Figure } 5\end{array}$ & Compound & Factor 1 & $\begin{array}{l}\text { Loading on } \\
\text { Factor } 2\end{array}$ & Factor 3 \\
\hline 1 & Octene & & & \\
\hline 2 & Octane & & & \\
\hline 3 & 2,4 (dimethy)-(1H)-pyrrole & -0.048 & 0.500 & 0.127 \\
\hline 4 & Dimethylbenzene & 0.660 & 0.083 & 0.592 \\
\hline 5 & 2,3-dimethylthiophene & 0.910 & -0.098 & 0.269 \\
\hline 6 & Nonene & 0.845 & 0.221 & 0.100 \\
\hline 7 & Nonane & 0.809 & -0.056 & 0.373 \\
\hline 8 & 2,3,4-trimethylthiophene & 0.623 & 0.027 & 0.551 \\
\hline 9 & 1-ethyl-2-methylbenzene & 0.468 & 0.104 & 0.810 \\
\hline 10 & Decane & 0.899 & -0.233 & -0.106 \\
\hline 11 & 1-methylphenol & 0.827 & 0.125 & 0.070 \\
\hline 12 & Undecene & 0.856 & 0.167 & -0.059 \\
\hline 13 & Undecane & 0.786 & 0.180 & 0.409 \\
\hline 14 & 1-methylindene & & & \\
\hline 15 & Dodecene & 0.867 & 0.274 & 0.078 \\
\hline 16 & Dodecane & 0.858 & 0.153 & 0.281 \\
\hline 17 & 2,6-dimethyl undecane & & & \\
\hline 18 & Tridecene & 0.760 & 0.367 & -0.093 \\
\hline 19 & Tridecane & 0.623 & 0.334 & 0.188 \\
\hline 20 & 1-methylnaphthalene & 0.929 & 0.084 & 0.245 \\
\hline 21 & 2,6,11-trimethyl dodecane & & & \\
\hline 22 & Benzothiophene & 0.929 & -0.016 & 0.186 \\
\hline 23 & Tetradecene & 0.874 & 0.333 & -0.039 \\
\hline 24 & Tetradecane & 0.814 & 0.365 & 0.370 \\
\hline 25 & Pentadecene & 0.767 & 0.522 & 0.239 \\
\hline 26 & Pentadecane & 0.666 & 0.491 & 0.390 \\
\hline 27 & Alkylbenzene & & & \\
\hline 28 & Hexadecene & 0.158 & 0.909 & 0.070 \\
\hline 29 & Hexadecane & 0.161 & 0.957 & 0.046 \\
\hline 30 & Heptadecene & 0.085 & 0.880 & 0.001 \\
\hline 31 & Heptadecane & 0.140 & 0.913 & 0.044 \\
\hline 32 & Pristane & 0.146 & 0.847 & 0.218 \\
\hline 33 & Prist-1-ene & -0.144 & 0.433 & 0.703 \\
\hline 34 & Prist-2-ene & 0.428 & 0.262 & 0.632 \\
\hline 35 & Octadecane & 0.068 & 0.908 & 0.014 \\
\hline 36 & Octadecene & 0.022 & 0.789 & 0.318 \\
\hline 37 & Phytane & 0.047 & 0.770 & 0.126 \\
\hline
\end{tabular}

Factor 2 (the amount of saturated and monounsaturated alkyl chains [16-18 carbon atoms] and isoprenoids pristane and phytane normalized to TOC) has no obvious correlation with the depositional environment on margin or ridge (Fig. 5, top), because scores on factor 2 are evenly distributed over margin and ridge samples alike. The scores of surface sediments on this factor are in the lower range of all samples, but overlap with those of all other samples. We consider this as an indication that the concentrations of the compounds that compose factor 2 is independent of organic matter quality and amount, as well as of depositional environment.

From the clusters of samples in Figure 5 (bottom), which plots cores of factor 1 against factor 3 , it appears that samples from Sites 723 and 728 contain relatively more alkylbenzene and long-chain isoprenoid hydrocarbons (prist-1-ene and prist-2-ene; 

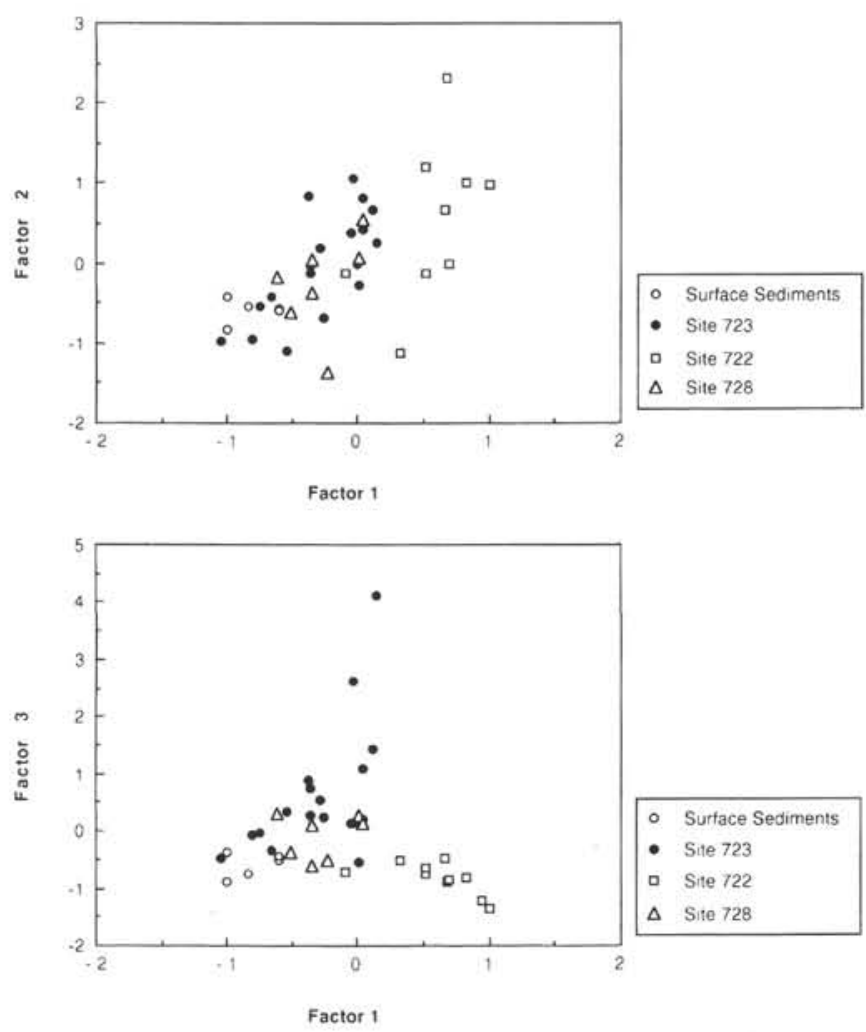

Figure 5. Plot of factor scores of samples on factors 1 and 2 (top) and factors 1 and 3 (bottom) extracted from the data matrix of 41 samples from Oman margin sediments. Note the separation of samples from Site 722. Factor 1 is dominated by concentrations of aromatic and heterocompounds (naphthalenes, thiophenes) and short-chain alkyl molecules $\left(C_{10}\right.$ to $\left.C_{15}\right)$, while factor 2 is dominated by straight-chain and branched alkanes and olefins of 16-20 carbon atoms. Factor 3 has highest contributions from alkylbenzene and unsaturated branched alkanes (prist-1ene, prist-2-ene) (compare Table 3).

factor 3) in their pyrolysates than either samples from the Owen Ridge (Site 722) and the surface sediments samples from the Oman margin. The amount of organic carbon has no influence on this relationship, but it is of note that highest scores on factor 3 occur in sediments of Site 723 in which laminations and opaline microfossils are preserved.

To distinguish any effect of burial diagenesis and variable depositional conditions through time on the moieties that compose factors 1 to 3 , we plotted depth profiles of factor scores (Fig. 6) for the sediments from margin Sites 723, 728, and surface sediments. In addition, we plotted the sum of the quantified hydrocarbons (in mg/g TOC), which is a "defined" hydrogen index (Fig. 6A). To discern any effect of bottom-water oxygenation (indicated by the presence of laminations) on the composition of pyrolysates in samples from Site 723 , we marked the depth range of the organic-rich and partly laminated interval deposited around the Pliocene/Pleistocene boundary at that site.

No consistent changes with depth are discernable in scores on factor 1 , the factor representing pyrolysates relatively enriched in aromatic and heterocompounds that we interpret to be indicative of degraded organic matter. Surface sediments have low scores on this factor (Fig. 6B), and variability in all margin sediments is rather low. Factor 2, however, which combines long-chain hydrocarbons, shows an increase with depth from surface sediments to the deeper samples of Site 723 . We take the increase of factor 2 with depth to indicate that the concentration of those kerogen moieties which yield long-chain $n$-alkyl pyrolysate are preferentially enriched in the organic matter with depth in the sediment (and thus with time; Fig. 6C). This relation holds for sediments from surface sediments and both Sites 723 and 728, and is in keeping with the hypothesis of a preferential preservation of a highly resistant, aliphatic, macromolecular precursor substance (algaenan; Tegelaar et al., 1989) in sedimentary organic matter that undergoes continuous biodegradation during anaerobic diagenesis.

A pronounced increase of scores on factor 3 and of the sum of quantified hydrocarbons shown in Figure $6 \mathrm{~A}$ is obvious in sediments from the sediment interval containing laminations at Site 723 (Fig. 6C). Kerogen moieties that yield prist-enes and methylbenzene upon pyrolysis are thus significantly enriched in the sediments deposited under conditions of impeded benthic activity. Van de Meent et al. (1980) believe that chlorophyll is the biological source of the sedimentary precursor substance that yields isoprenoid hydrocarbons prist-1-ene and prist-2-ene upon pyrolysis. According to the results of Goossens et al. (1984), other likely precursor substances are tocopherols. With the data at hand, we can draw the conclusion that the precursor substance of prist-enes and alkylbenzene is preferentially preserved in sediments that were deposited under low oxygen or even anoxic conditions at the sediment-water interface, without being able to decide the origin of these abundant pyrolysis products.

\section{CONCLUSIONS}

1. The main variability in this dataset is the difference between pyrolysates from sediments underneath upwelling cells and those that were deposited several hundreds of miles offshore on Owen Ridge. The latter contain more heterocompounds, and alkane/alkene doublets in the range from $\mathrm{C}_{9}$ to $\mathrm{C}_{14}$. In light of the predominance of marine organic matter at all locations studied, we suggest that the observed differences, notably the abundance of aromatic molecules and heterocompounds, are related to the degree of reworking prior to deposition.

2. Individual molecular building blocks of kerogen or humus are preferentially enriched during diagenesis in our samples. The amount of long-chain alkane/alkene doublets (range from $C_{16}$ to $C_{18}$ ) relative to TOC increases with depth at the Oman Margin sites.

3 . If we use the macroscopic facies differences of bioturbation vs. lamination as a guideline for determining past extents and intensities of the oxygen minimum zone on the Oman shelf, our attempt to chemically distinguish sediments from anaerobic and aerobic depositional conditions was successful, if somewhat ambiguous. Specific groups of pyrolyzable compounds, namely those that yield monounsaturated isoprenoid hydrocarbons prist1-ene and prist-2-ene and alkylbenzene appear to be enriched in samples with high HI, and may be indicative of molecular differences in sedimentary organic matter from the two types of environments.

\section{ACKNOWLEDGMENTS}

We thank Martha Tarafa and Peggy Dickinson for analytical help, and Carl Johnson for assistance with the mass spectroscopy. Dave Anderson, Mark McCaffrey, John Farrington, and Remy Hennet provided valuable samples, discussion, comments, and data. The authors gratefully acknowledge financial support by USSAC and Shell Development Company, and technical support by the Ocean Drilling Program. This work was supported by the National Science Foundation, Grant No. OCE 85-09859. This is Woods Hole Oceanographic Institution contribution No. 7527. 


\section{REFERENCES}

Barker, C., and Wang, L., 1988. Applications of pyrolysis in petroleum geochemistry: a bibliography. J. Anal. Appl. Pyrol., 13:9-61.

Demaison, G. J., and Moore, G. T., 1980. Anoxic environments and oil source bed genesis. Org. Geochem., 2, 9-31.

Durand, B., 1980. Kerogen. Paris (Editions Technip).

Emeis, K.-C., and Morse, J. W., 1990. Relationship of organic carbon to sulfur in sediments from the Peru margin, ODP Sites 680 and 688. In Suess, E., von Huene, R., et al., Proc. ODP, Sci. Results, 112. College Station, TX (Ocean Drilling Program), 441-453.

Emeis, K.-C., Whelan, J. K., and Tarafa, M., in press. Sedimentary and geochemical expression of oxic and anoxic conditions on the Peru shelf. In Tyson, R., and Pearson, T. (Eds.) Continental Shelf Anoxia. Geol. Soc. London Spec. Publ.

Espitalié, J., Laporte, J. L., Madec, M., Marquis, F., Leplat, P., Paulet, J., and Boutefeu, A., 1977. Méthode rapide de caractérisation des roches mères, de leur potentiel pétrolier et de leur degré d'évolution. Rev. Inst. Fr. Pétrole, 32:23-42.

Goossens, H., de Leeuw, J. W., Schenk, P. A., and Brassell, S. C., 1984. Tocopherols as likely precursors of pristane in ancient sediments and crude oils. Nature, 312:440-442.

Henrichs, S. M., and Reeburgh, W. S., 1987. Anaerobic remineralization of marine sediment organic matter: rates and the role of anaerobic processes in the oceanic carbon economy. J. Geomicrobiol., 5: 191-237.

Howarth, R. J., and Sinding-Larsen, R., 1983. Multivariate Analysis. In Howarth, R. J., (Ed.) Statistics and Data Analysis in Geochemical Prospecting. Handbook of Exploration Geology, Vol. 2. Elsevier (Amsterdam), 207-289.

Katz, B. J., 1983. Limitations of "Rock-Eval" pyrolysis for typing organic matter. Org. Geochem., 4:195-199.

Mountain, G. S., and Prell, W. L., 1989. Geophysical reconnaissance for ODP Leg 117 in the northwest Indian Ocean. In Prell, W. D. Niitsuma, N., et al., Proc. ODP, Init. Repts., 117: College Station, TX (Ocean Drilling Program), 51-64.

Nip., M., Tegelaar, E. W., de Leeuw, J. W., Schenk, P. A., and Holloway, P. J., 1986. A new non-saponifiable highly aliphatic and resistant biopolymer in plant cuticles: evidence from pyrolysis and ${ }^{13} \mathrm{C}$ NMR analysis of present-day and fossil plants. Naturwissenschaften, 73:579-585.

Øygard, K., Larter, S., and Senftle, J., 1988. The control of maturity and kerogen type on quantitative analytical pyrolysis data. Org. Geochem. 13:1153-1162.

Pratt, L. M., Claypool, G. E., and King, J. D., 1986. Geochemical imprint of depositional conditions on organic matter in laminated-bioturbated interbeds from fine-grained marine sequences. Mar. Geol., 70:67-84.

Prell, W. L., Niitsuma, N., et al., 1989. Proc. ODP, Init. Repts., 117: College Station, TX (Ocean Drilling Program).

Rhoads, D. C., and Morse, J. W., 1971. Evolutionary and ecological significance of oxygen-deficient marine basins. Lethaia, 4:413-428.

Tarafa, M. E., Whelan, J. K., and Mountain, G. S., 1987. Sediment slumps in the Middle and Lower Eocene of Deep Sea Drilling Project Holes 605 and 613: Chemical detection by pyrolysis techniques. In Poag, C. W., Watts, A. B., et al., Init. Repts. DSDP, 95, Washington (U.S. Govt. Printing Office), 661-669.

Tegelaar, E. W., de Leeuw, J. W., Derenne, S., and Largeau, C., 1989. A reappraisal of kerogen formation. Geochim. Cosmochim. Acta, 53: 3103-3106.

Van de Meent, D., Brown, S. C., Philp, R. P., and Simoneit, B.R.T., 1980. Pyrolysis-high-resolution gas chromatography and pyrolysis gas-chromatography-mass spectrometry of kerogens and kerogen precursors. Geochim. Cosmochim. Acta, 44:999-1013.

Whelan, J. K., Kanyo, Z., Tarafa, M., and McCaffrey, M. A., 1990. Organic matter in Peru upwelling sediments-analysis by pyrolysis-GC and -GCMS. In Suess, E., von Huene, R., et al., Proc. ODP, Sci. Results, 112. College Station, TX (Ocean Drilling Program), 573590 .
Wyrtki, K., 1973. Physical oceanography of the Indian Ocean. In Zeitschel, B., and Gerlach, S. A. (Eds.) The Biology of the Indian Ocean: New York (Springer-Verlag), 18-36.

Date of initial receipt: 28 June 1989

Date of acceptance: 23 February 1990

Ms 117B-158
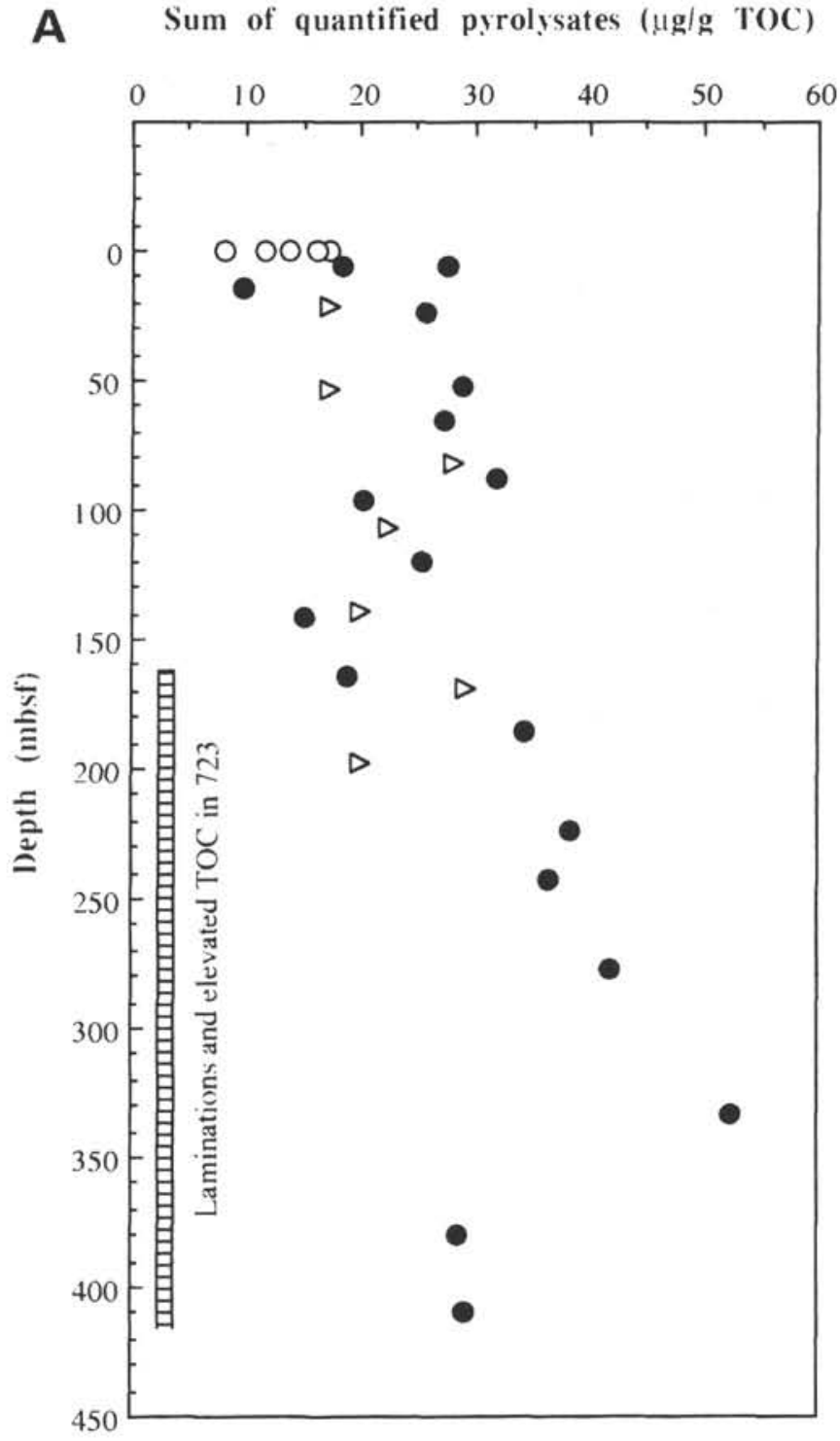

Figure 6. Downhole plots of the sum of hydrocarbons quantified in each pyrolysate (A), factor 1 (B), factor 2 (C), and factor 3 (D) with depth to show downhole variability for surface cores (circles), samples of Site 723 (dots) and 728 (triangles). The interval in Site 723 where organic carbon increases and laminations are preserved is indicated. See text for discussion. 
B

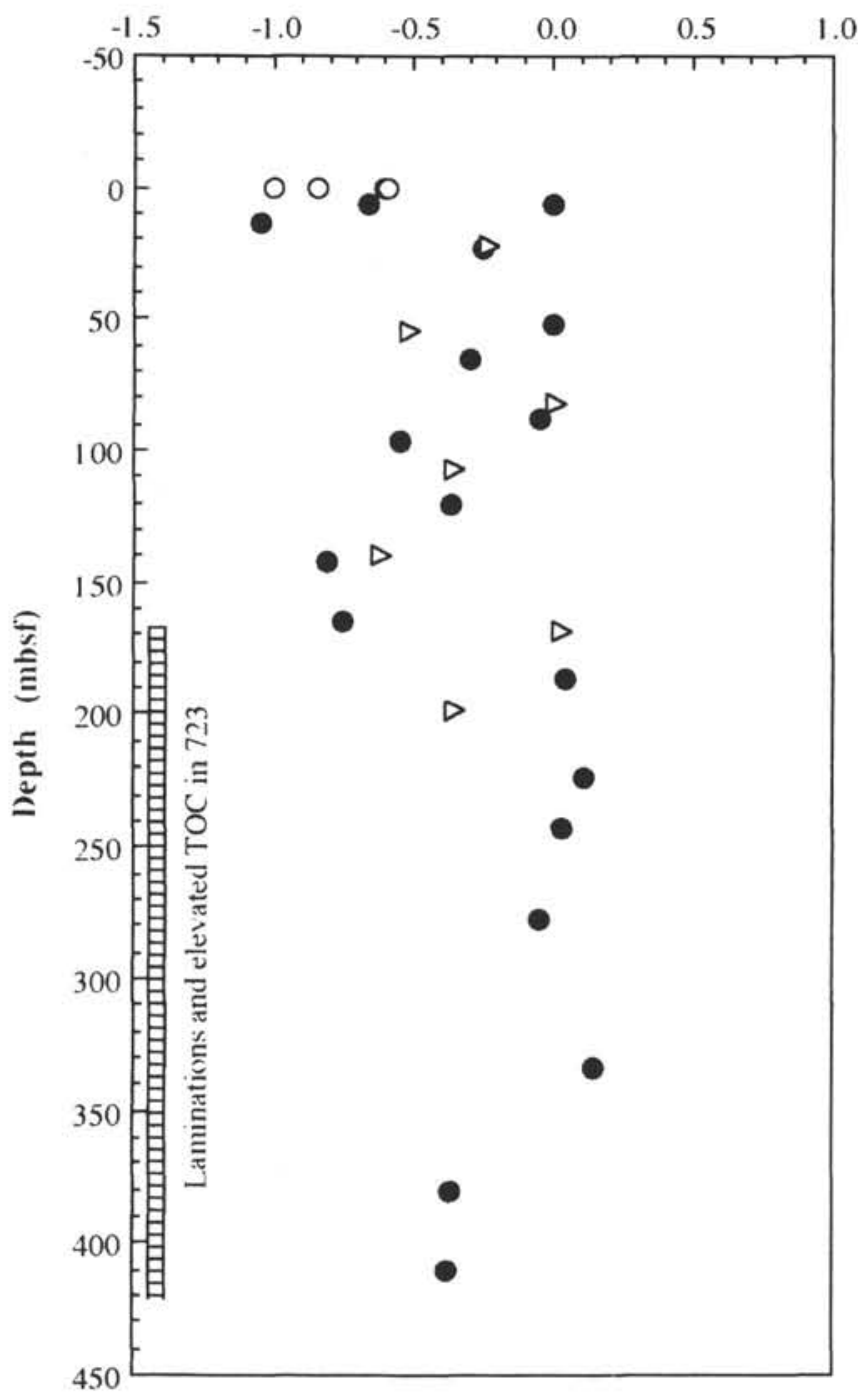

Figure 6 (continued).
C Scores on factor 2

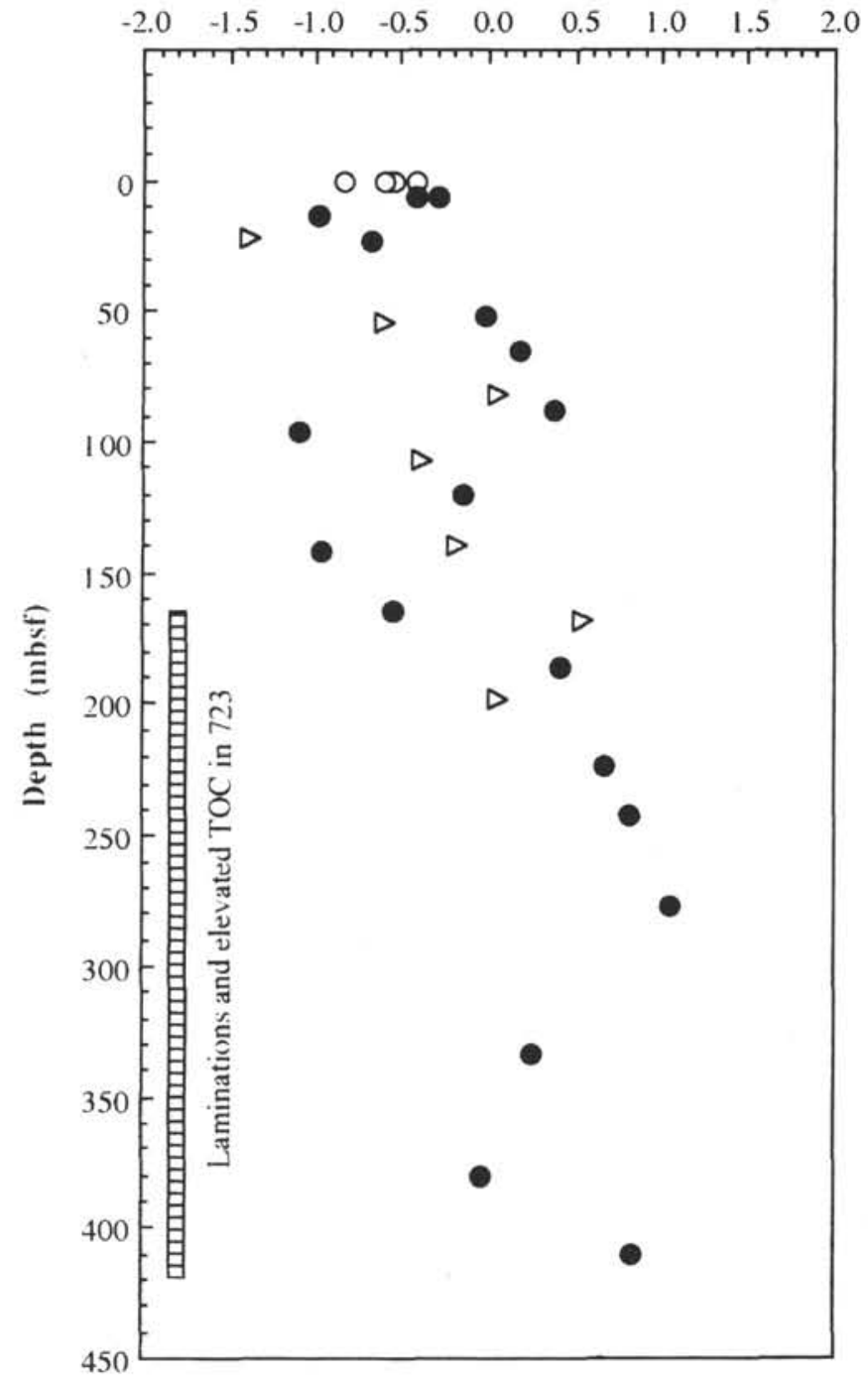

Figure 6 (continued). 


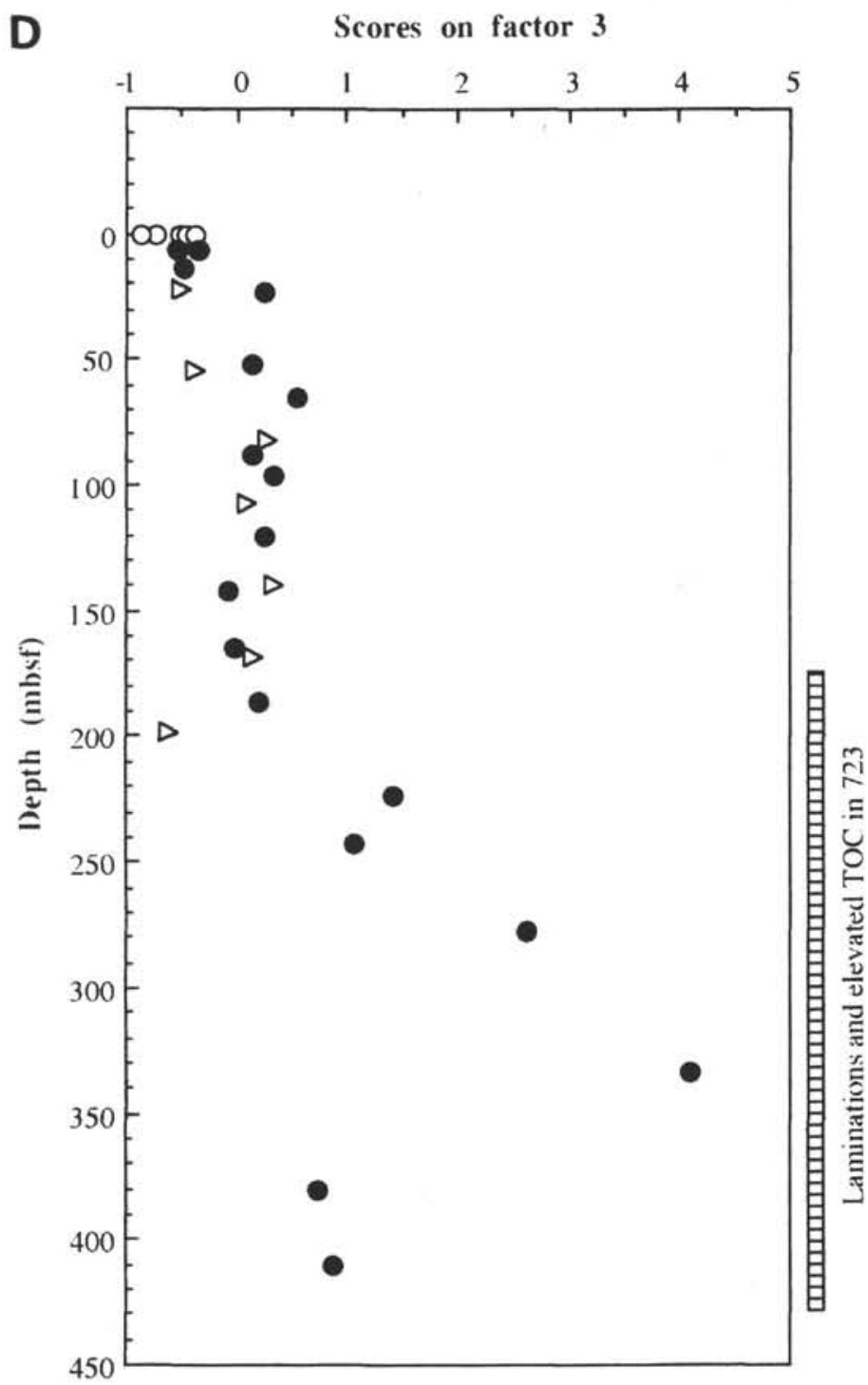

Figure 6 (continued). 
Table 3. Results of pyrolysis-gas chromatography from 41 samples from surface sediments, Sites 723, 728, and 722. Results are normalized to TOC, and factor scores are given in the last columns.

\begin{tabular}{|c|c|c|c|c|c|c|c|c|c|c|}
\hline Sample & $\begin{array}{l}\text { Depth } \\
\text { (mbsf) }\end{array}$ & $\begin{array}{c}\text { Carbonate } \\
(\%)\end{array}$ & $\begin{array}{l}\text { TOC } \\
(\%)\end{array}$ & $\begin{array}{c}\text { HI CDS } \\
(\mathrm{mg} / \mathrm{g} \text { TOC) }\end{array}$ & $\begin{array}{c}\mathrm{C}_{9} \text {-ene } \\
(\mu \mathrm{g} / \mathrm{g} \text { TOC })\end{array}$ & $\begin{array}{c}C_{9} \text {-ane } \\
(\mu \mathrm{g} / \mathrm{g} \text { TOC })\end{array}$ & $\begin{array}{c}\mathrm{C}_{10^{-a n e}} \\
(\mu \mathrm{g} / \mathrm{g} \text { TOC })\end{array}$ & $\begin{array}{c}\mathrm{C}_{11} \text {-ene } \\
(\mu \mathrm{g} / \mathrm{g} \text { TOC })\end{array}$ & $\begin{array}{c}\mathrm{C}_{11 \text {-ane }} \\
(\mu \mathrm{g} / \mathrm{g} \text { TOC })\end{array}$ & $\begin{array}{c}C_{12 \text {-ene }} \\
(\mu \mathrm{g} / \mathrm{g} \text { TOC })\end{array}$ \\
\hline RC2709 & 0.0 & 44.0 & 6.50 & 253 & 772 & 491 & 334 & 629 & 932 & 1482 \\
\hline $\mathrm{RC} 2712$ & 0.0 & 47.0 & 7.40 & 246 & 0 & 0 & 293 & 476 & 697 & 1159 \\
\hline $\mathrm{RC} 2714$ & 0.0 & 40.0 & 4.70 & 236 & 0 & 0 & 315 & 504 & 830 & 862 \\
\hline $\mathrm{RC} 2723$ & 0.0 & 43.0 & 8.00 & 296 & 0 & 0 & 346 & 331 & 476 & 846 \\
\hline $\mathrm{RC} 2724$ & 0.0 & 64.0 & 2.70 & 318 & 0 & 0 & 467 & 889 & 374 & 515 \\
\hline \multicolumn{11}{|l|}{$723 \mathrm{~A}-$} \\
\hline $1 \mathrm{H}-4,144-145 \mathrm{~cm}$ & 5.9 & 50.2 & 1.80 & 647 & 0 & 0 & 1400 & 2372 & 1328 & 1072 \\
\hline $1 \mathrm{H}-4,145-150 \mathrm{~cm}$ & 5.9 & 50.2 & 1.80 & 247 & 0 & 0 & 644 & 1589 & 722 & 889 \\
\hline $2 \mathrm{H}-3,149-150 \mathrm{~cm}$ & 14.1 & - & 3.50 & 151 & 0 & 0 & 254 & 571 & 629 & 631 \\
\hline $3 \mathrm{H}-4,144-145 \mathrm{~cm}$ & 23.4 & 56.4 & 0.71 & 289 & 1197 & 1056 & 775 & 972 & 1141 & 845 \\
\hline $6 \mathrm{H}-4,144-145 \mathrm{~cm}$ & 52.3 & 63.9 & 2.04 & 414 & 1387 & 1127 & 995 & 2289 & 1201 & 1152 \\
\hline $7 \mathrm{H}-2,149-150 \mathrm{~cm}$ & 65.5 & 60.5 & 4.50 & 372 & 1237 & 851 & 747 & 1131 & 1020 & 1402 \\
\hline $9 \mathrm{H}-4,144-145 \mathrm{~cm}$ & 87.7 & 57.8 & 2.42 & 490 & 926 & 880 & 888 & 983 & 752 & 1351 \\
\hline $11 X-1,149-150 \mathrm{~cm}$ & 96.3 & 50.4 & 1.10 & 205 & 809 & 536 & 536 & 545 & 855 & 573 \\
\hline $13 \mathrm{X}-4,149-150 \mathrm{~cm}$ & 119.8 & 63.3 & 3.50 & 397 & 1303 & 1169 & 560 & 1026 & 940 & 1223 \\
\hline $16 \times-2,149-150 \mathrm{~cm}$ & 142.1 & - & 2.80 & 167 & 518 & 521 & 546 & 1161 & 579 & 493 \\
\hline $18 \mathrm{X}-5,0-1 \mathrm{~cm}$ & 164.6 & - & 3.35 & 236 & 0 & 0 & 549 & 1343 & 785 & 740 \\
\hline $20 \mathrm{X}-4,0-5 \mathrm{~cm}$ & 186.3 & 60.9 & 2.60 & 423 & 1184 & 1181 & 808 & 2542 & 1096 & 1308 \\
\hline $24 \mathrm{X}-3,0-1 \mathrm{~cm}$ & 223.4 & 44.5 & 4.50 & 485 & 942 & 1133 & 844 & 1302 & 1264 & 1482 \\
\hline $26 \mathrm{X}-3,0-1 \mathrm{~cm}$ & 242.8 & 53.2 & 5.60 & 496 & 1330 & 993 & 932 & 1568 & 1189 & 1605 \\
\hline $29 \mathrm{X}-6,119-120 \mathrm{~cm}$ & 277.4 & 29.4 & 4.40 & 532 & 1257 & 1364 & 759 & 1648 & 2030 & 1275 \\
\hline $36 \mathrm{X}-5,145-150 \mathrm{~cm}$ & 333.6 & 35.7 & 2.90 & 379 & 1362 & 1555 & 0 & 1148 & 2831 & 2069 \\
\hline $38 X-5,145-150 \mathrm{~cm}$ & 380.0 & - & 4.17 & 561 & 1046 & 947 & 688 & 2053 & 1014 & 1067 \\
\hline $41 \times-2,0-1 \mathrm{~cm}$ & 410.0 & 43.0 & 5.50 & 383 & 1006 & 922 & 507 & 1289 & 909 & 944 \\
\hline \multicolumn{11}{|l|}{$728 \mathrm{~A}-$} \\
\hline $3 \mathrm{H}-4,119-120 \mathrm{~cm}$ & 21.4 & 57.1 & 1.04 & 233 & 885 & 721 & 1173 & 1048 & 808 & 644 \\
\hline $6 \mathrm{H}-4,119-120 \mathrm{~cm}$ & 53.9 & 52.0 & 2.27 & 192 & 652 & 476 & 740 & 1344 & 793 & 947 \\
\hline $9 \mathrm{H}-4,119-120 \mathrm{~cm}$ & 81.8 & 51.2 & 4.97 & 358 & 972 & 827 & 841 & 1421 & 1805 & 1000 \\
\hline $12 \mathrm{X}-2,119-120 \mathrm{~cm}$ & 107.6 & 49.4 & 2.95 & 353 & 841 & 692 & 820 & 841 & 1207 & 834 \\
\hline $15 \mathrm{X}-4,119-120 \mathrm{~cm}$ & 139.6 & 56.5 & 3.40 & 410 & 650 & 497 & 591 & 579 & 1191 & 938 \\
\hline $18 \times-4,119-120 \mathrm{~cm}$ & 168.5 & 71.6 & 2.76 & 446 & 1203 & 899 & 859 & 1391 & 1699 & 681 \\
\hline $21 X-5,0-1 \mathrm{~cm}$ & 197.8 & 49.6 & 3.11 & 279 & 711 & 527 & 640 & 1424 & 1087 & 1248 \\
\hline \multicolumn{11}{|l|}{$722 \mathrm{~A}-$} \\
\hline $16 \mathrm{X}-2,20-21 \mathrm{~cm}$ & 146.3 & 86.8 & 0.02 & 2230 & 3500 & 3500 & 4500 & 5000 & 3500 & 4000 \\
\hline $16 \times-2,25-27 \mathrm{~cm}$ & 146.4 & 84.1 & 0.44 & 237 & 1682 & 955 & 955 & 1614 & 1159 & 1500 \\
\hline $16 \mathrm{X}-2,29-30 \mathrm{~cm}$ & 146.4 & 81.6 & 0.58 & 275 & 1776 & 1000 & 983 & 1810 & 1345 & 1293 \\
\hline $16 \mathrm{X}-2,43-44 \mathrm{~cm}$ & 146.5 & 71.1 & 1.94 & 312 & 1835 & 1216 & 1428 & 2397 & 1577 & 1572 \\
\hline $16 \mathrm{X}-2,48-49 \mathrm{~cm}$ & 146.6 & 67.1 & 1.93 & 518 & 2052 & 0 & 264 & 2295 & 1363 & 2617 \\
\hline $16 X-2,60-61 \mathrm{~cm}$ & 146.7 & 57.1 & 1.94 & 345 & 2005 & 1412 & 1088 & 2515 & 1309 & 1531 \\
\hline $16 \times-2,69-70 \mathrm{~cm}$ & 146.8 & 56.6 & 2.06 & 317 & 1709 & 1291 & 1364 & 2515 & 1777 & 2398 \\
\hline \multicolumn{11}{|l|}{$722 B-$} \\
\hline $29-3,140-141 \mathrm{~cm}$ & 270.3 & 41.6 & 2.17 & 162 & 1203 & 959 & 756 & 1336 & 908 & 1180 \\
\hline $29 \mathrm{X}-3,130-131 \mathrm{~cm}$ & 270.2 & 44.7 & 2.24 & 413 & 1013 & 938 & 1451 & 2634 & 2205 & 2063 \\
\hline $29 \mathrm{X}-4,20-21 \mathrm{~cm}$ & 270.6 & 35.7 & 1.10 & 356 & 1664 & 1073 & 1436 & 1882 & 1609 & 1764 \\
\hline $29 X-4,60-61 \mathrm{~cm}$ & 271.0 & 73.0 & 0.27 & 231 & 1185 & 815 & 1037 & 1444 & 778 & 852 \\
\hline
\end{tabular}


Table 3 (continued).

\begin{tabular}{|c|c|c|c|c|c|c|c|c|c|}
\hline Sample & $\begin{array}{l}\text { Depth } \\
\text { (mbsf) }\end{array}$ & $\begin{array}{c}C_{12 \text {-ane }} \\
(\mu \mathrm{g} / \mathrm{g} \text { TOC })\end{array}$ & $\begin{array}{c}C_{13} \text {-ene } \\
(\mu \mathrm{g} / \mathrm{g} \text { TOC })\end{array}$ & $\begin{array}{c}C_{13 \text {-ane }} \\
(\mu \mathrm{g} / \mathrm{g} \text { TOC })\end{array}$ & $\begin{array}{l}C_{14} \text {-ene } \\
(\mu \mathrm{g} / \mathrm{g} \text { TOC })\end{array}$ & $\begin{array}{c}C_{14^{-a n e}} \\
(\mu \mathrm{g} / \mathrm{g} \text { TOC })\end{array}$ & $\begin{array}{c}C_{15} \text {-ene } \\
(\mu \mathrm{g} / \mathrm{g} \text { TOC })\end{array}$ & $\begin{array}{c}C_{15} \text {-ane } \\
(\mu \mathrm{g} / \mathrm{g} \text { TOC })\end{array}$ & $\begin{array}{c}C_{16} \text {-ene } \\
(\mu \mathrm{g} / \mathrm{g} \text { TOC })\end{array}$ \\
\hline $\mathrm{RC} 2709$ & 0.0 & 429 & 529 & 343 & 529 & 282 & 358 & 403 & 298 \\
\hline $\mathrm{RC} 2712$ & 0.0 & 355 & 508 & 305 & 504 & 277 & 351 & 374 & 286 \\
\hline $\mathrm{RC} 2714$ & 0.0 & 566 & 536 & 830 & 998 & 462 & 451 & 409 & 264 \\
\hline $\mathrm{RC} 2723$ & 0.0 & 318 & 458 & 295 & 821 & 270 & 463 & 436 & 285 \\
\hline $\mathrm{RC} 2724$ & 0.0 & 296 & 522 & 270 & 352 & 226 & 315 & 204 & 226 \\
\hline \multicolumn{10}{|l|}{$723 \mathrm{~A}-$} \\
\hline $1 \mathrm{H}-4,144-145 \mathrm{~cm}$ & 5.9 & 544 & 2589 & 606 & 422 & 544 & 511 & 461 & 361 \\
\hline $1 \mathrm{H}-4,145-150 \mathrm{~cm}$ & 5.9 & 406 & 811 & 306 & 956 & 528 & 500 & 372 & 383 \\
\hline $2 \mathrm{H}-3,149-150 \mathrm{~cm}$ & 14.1 & 240 & 380 & 169 & 434 & 226 & 211 & 197 & 149 \\
\hline $3 \mathrm{H}-4,144-145 \mathrm{~cm}$ & 23.4 & 577 & 1070 & 394 & 831 & 535 & 521 & 465 & 310 \\
\hline $6 \mathrm{H}-4,144-145 \mathrm{~cm}$ & 52.3 & 637 & 1147 & 490 & 1353 & 922 & 696 & 559 & 446 \\
\hline $7 \mathrm{H}-2,149-150 \mathrm{~cm}$ & 65.5 & 562 & 876 & 562 & 1284 & 824 & 902 & 660 & 531 \\
\hline $9 \mathrm{H}-4,144-145 \mathrm{~cm}$ & 87.7 & 727 & 2070 & 661 & 1240 & 983 & 851 & 558 & 285 \\
\hline $11 X-1,149-150 \mathrm{~cm}$ & 96.3 & 364 & 645 & 609 & 782 & 473 & 373 & 309 & 145 \\
\hline $13 \mathrm{X}-4,149-150 \mathrm{~cm}$ & 119.8 & 449 & 820 & 389 & 1011 & 723 & 709 & 680 & 526 \\
\hline $16 \mathrm{X}-2,149-150 \mathrm{~cm}$ & 142.1 & 254 & 536 & 150 & 661 & 421 & 300 & 250 & 186 \\
\hline $18 \mathrm{X}-5,0-1 \mathrm{~cm}$ & 164.6 & 337 & 669 & 221 & 785 & 537 & 367 & 331 & 209 \\
\hline $20 X-4,0-5 \mathrm{~cm}$ & 186.3 & 658 & 1027 & 500 & 1477 & 942 & 965 & 635 & 465 \\
\hline $24 X-3,0-1 \mathrm{~cm}$ & 223.4 & 558 & 1396 & 840 & 1829 & 1171 & 1207 & 1300 & 1000 \\
\hline $26 \mathrm{X}-3,0-1 \mathrm{~cm}$ & 242.8 & 641 & 1080 & 634 & 1650 & 1271 & 1125 & 1096 & 741 \\
\hline $29 X-6,119-120 \mathrm{~cm}$ & 277.4 & 627 & 1382 & 768 & 1716 & 1273 & 1039 & 1450 & 927 \\
\hline $36 \mathrm{X}-5,145-150 \mathrm{~cm}$ & 333.6 & 1928 & 734 & 1631 & 538 & 2124 & 1359 & 972 & 497 \\
\hline $38 \mathrm{X}-5,145-150 \mathrm{~cm}$ & 380.0 & 530 & 988 & 408 & 1211 & 823 & 830 & 578 & 453 \\
\hline $41 X-2,0-1 \mathrm{~cm}$ & 410.0 & 685 & 1073 & 945 & 1182 & 975 & 920 & 1136 & 820 \\
\hline \multicolumn{10}{|l|}{$728 \mathrm{~A}-$} \\
\hline $3 \mathrm{H}-4,119-120 \mathrm{~cm}$ & 21.4 & 538 & 702 & 413 & 962 & 596 & 404 & 471 & 96 \\
\hline $6 \mathrm{H}-4,119-120 \mathrm{~cm}$ & 53.9 & 414 & 714 & 330 & 833 & 551 & 511 & 467 & 269 \\
\hline $9 \mathrm{H}-4,119-120 \mathrm{~cm}$ & 81.8 & 773 & 994 & 911 & 1199 & 817 & 891 & 313 & 414 \\
\hline $12 \mathrm{X}-2,119-120 \mathrm{~cm}$ & 107.6 & 441 & 820 & 407 & 1180 & 786 & 302 & 380 & 308 \\
\hline $15 \times-4,119-120 \mathrm{~cm}$ & 139.6 & 391 & 956 & 415 & 971 & 685 & 574 & 397 & 329 \\
\hline $18 \times-4,119-120 \mathrm{~cm}$ & 168.5 & 710 & 1051 & 1344 & 1402 & 917 & 1004 & 558 & 558 \\
\hline $21 X-5,0-1 \mathrm{~cm}$ & 197.8 & 405 & 842 & 360 & 1190 & 685 & 405 & 521 & 338 \\
\hline \multicolumn{10}{|l|}{$722 \mathrm{~A}-$} \\
\hline $16 \mathrm{X}-2,20-21 \mathrm{~cm}$ & 146.3 & 2500 & 3000 & 1500 & 4000 & 2500 & 2000 & 1500 & 0 \\
\hline $16 \mathrm{X}-2,25-27 \mathrm{~cm}$ & 146.4 & 659 & 1227 & 1341 & 1227 & 1341 & 1068 & 659 & 773 \\
\hline $16 \mathrm{X}-2,29-30 \mathrm{~cm}$ & 146.4 & 724 & 1379 & 552 & 1586 & 914 & 776 & 621 & 466 \\
\hline $16 \mathrm{X}-2,43-44 \mathrm{~cm}$ & 146.5 & 881 & 1603 & 784 & 1881 & 1170 & 1072 & 763 & 789 \\
\hline $16 \mathrm{X}-2,48-49 \mathrm{~cm}$ & 146.6 & 1383 & 2591 & 1119 & 2663 & 1782 & 1922 & 1254 & 1446 \\
\hline $16 \mathrm{X}-2,60-61 \mathrm{~cm}$ & 146.7 & 990 & 1077 & 706 & 1876 & 1211 & 1124 & 835 & 923 \\
\hline $16 \mathrm{X}-2,69-70 \mathrm{~cm}$ & 146.8 & 869 & 1563 & 718 & 1903 & 1340 & 1398 & 850 & 850 \\
\hline \multicolumn{10}{|l|}{$722 \mathrm{~B}-$} \\
\hline $29-3,140-141 \mathrm{~cm}$ & 270.3 & 687 & 986 & 525 & 1069 & 751 & 641 & 677 & 484 \\
\hline $29 \mathrm{X}-3,130-131 \mathrm{~cm}$ & 270.2 & 1031 & 2179 & 897 & 2165 & 1344 & 1232 & 964 & 920 \\
\hline $29 X-4,20-21 \mathrm{~cm}$ & 270.6 & 955 & 1655 & 2118 & 1964 & 1145 & 900 & 964 & 582 \\
\hline $29 \times-4,60-61 \mathrm{~cm}$ & 271.0 & 630 & 963 & 556 & 1037 & 889 & 519 & 593 & 222 \\
\hline
\end{tabular}


Table 3 (continued).

\begin{tabular}{|c|c|c|c|c|c|c|c|c|c|}
\hline Sample & $\begin{array}{l}\text { Depth } \\
\text { (mbsf) }\end{array}$ & $\begin{array}{c}\mathrm{C}_{16} \text {-ane } \\
(\mu \mathrm{g} / \mathrm{g} \text { TOC })\end{array}$ & $\begin{array}{c}\mathrm{C}_{17} \text {-ene } \\
(\mu \mathrm{g} / \mathrm{g} \text { TOC })\end{array}$ & $\begin{array}{c}\mathrm{C}_{17} \gamma^{\text {ane }} \\
(\mu \mathrm{g} / \mathrm{g} \text { TOC })\end{array}$ & $\begin{array}{l}\text { Prist-1-ene } \\
(\mu \mathrm{g} / \mathrm{g} \text { TOC })\end{array}$ & $\begin{array}{c}\mathrm{C}_{18} \text {-ene } \\
(\mu \mathrm{g} / \mathrm{g} \text { TOC })\end{array}$ & $\begin{array}{c}\mathrm{C}_{18^{-a n e}} \\
(\mu \mathrm{g} / \mathrm{g} \text { TOC })\end{array}$ & $\begin{array}{l}\text { Prist-2-ene } \\
(\mu \mathrm{g} / \mathrm{g} \text { TOC })\end{array}$ & $\begin{array}{c}\text { Pristane } \\
(\mu \mathrm{g} / \mathrm{g} \text { TOC })\end{array}$ \\
\hline RC2709 & 0.0 & 257 & 337 & 288 & 411 & 200 & 335 & 117 & 15 \\
\hline RC2712 & 0.0 & 223 & 336 & 277 & 322 & 195 & 341 & 103 & 18 \\
\hline RC2714 & 0.0 & 228 & 215 & 389 & 304 & 151 & 287 & 130 & 0 \\
\hline $\mathrm{RC} 2723$ & 0.0 & 244 & 305 & 299 & 593 & 226 & 365 & 219 & 43 \\
\hline RC2724 & 0.0 & 178 & 181 & 167 & 193 & 152 & 244 & 81 & 30 \\
\hline \multicolumn{10}{|l|}{$723 \mathrm{~A}-$} \\
\hline $1 \mathrm{H}-4,144-145 \mathrm{~cm}$ & 5.9 & 272 & 778 & 100 & 367 & 300 & 539 & 594 & 167 \\
\hline $1 \mathrm{H}-4,145-150 \mathrm{~cm}$ & 5.9 & 250 & 344 & 300 & 411 & 217 & 339 & 494 & 89 \\
\hline $2 \mathrm{H}-3,149-150 \mathrm{~cm}$ & 14.1 & 126 & 303 & 103 & 149 & 94 & 197 & 280 & 31 \\
\hline $3 \mathrm{H}-4,144-145 \mathrm{~cm}$ & 23.4 & 268 & 268 & 268 & 197 & 197 & 437 & 282 & 127 \\
\hline $6 \mathrm{H}-4,144-145 \mathrm{~cm}$ & 52.3 & 368 & 392 & 480 & 804 & 348 & 539 & 539 & 137 \\
\hline $7 \mathrm{H}-2,149-150 \mathrm{~cm}$ & 65.5 & 478 & 496 & 427 & 1151 & 322 & 513 & 356 & 162 \\
\hline $9 \mathrm{H}-4,144-145 \mathrm{~cm}$ & 87.7 & 504 & 674 & 492 & 1145 & 492 & 463 & 331 & 211 \\
\hline $11 X-1,149-150 \mathrm{~cm}$ & 96.3 & 136 & 164 & 164 & 155 & 100 & 209 & 227 & 91 \\
\hline $13 \times-4,149-150 \mathrm{~cm}$ & 119.8 & 357 & 343 & 323 & 717 & 246 & 400 & 280 & 120 \\
\hline $16 \mathrm{X}-2,149-150 \mathrm{~cm}$ & 142.1 & 146 & 143 & 143 & 211 & 364 & 132 & 236 & 89 \\
\hline $18 X-5,0-1 \mathrm{~cm}$ & 164.6 & 203 & 299 & 328 & 397 & 236 & 382 & 573 & 128 \\
\hline $20 X-4,0-5 \mathrm{~cm}$ & 186.3 & 446 & 488 & 550 & 846 & 442 & 665 & 527 & 169 \\
\hline $24 \mathrm{X}-3,0-1 \mathrm{~cm}$ & 223.4 & 627 & 618 & 580 & 1269 & 402 & 689 & 644 & 91 \\
\hline 26X-3, 0-1 cm & 242.8 & 618 & 627 & 727 & 1546 & 377 & 486 & 332 & 229 \\
\hline $29 \mathrm{X}-6,119-120 \mathrm{~cm}$ & 277.4 & 616 & 582 & 580 & 1416 & 1105 & 439 & 768 & 425 \\
\hline $36 \mathrm{X}-5,145-150 \mathrm{~cm}$ & 333.6 & 534 & 628 & 669 & 1228 & 466 & 614 & 1300 & 224 \\
\hline $38 \mathrm{X}-5,145-150 \mathrm{~cm}$ & 380.0 & 367 & 410 & 444 & 976 & 400 & 561 & 444 & 146 \\
\hline $41 X-2,0-1 \mathrm{~cm}$ & 410.0 & 600 & 433 & 462 & 1264 & 367 & 725 & 324 & 289 \\
\hline \multicolumn{10}{|l|}{$728 \mathrm{~A}-$} \\
\hline $3 \mathrm{H}-4,119-120 \mathrm{~cm}$ & 21.4 & 96 & 87 & 115 & 29 & 19 & 58 & 0 & 0 \\
\hline $6 \mathrm{H}-4,119-120 \mathrm{~cm}$ & 53.9 & 278 & 304 & 308 & 251 & 185 & 229 & 278 & 75 \\
\hline $9 \mathrm{H}-4,119-120 \mathrm{~cm}$ & 81.8 & 374 & 473 & 811 & 652 & 201 & 221 & 233 & 171 \\
\hline $12 \mathrm{X}-2,119-120 \mathrm{~cm}$ & 107.6 & 312 & 346 & 583 & 271 & 261 & 298 & 447 & 153 \\
\hline $15 \mathrm{X}-4,119-120 \mathrm{~cm}$ & 139.6 & 326 & 503 & 421 & 809 & 344 & 371 & 462 & 106 \\
\hline $18 \mathrm{X}-4,119-120 \mathrm{~cm}$ & 168.5 & 547 & 873 & 583 & 793 & 464 & 493 & 428 & 138 \\
\hline $21 X-5,0-1 \mathrm{~cm}$ & 197.8 & 350 & 714 & 424 & 148 & 344 & 386 & 286 & 177 \\
\hline \multicolumn{10}{|l|}{$722 \mathrm{~A}$ - } \\
\hline $16 \mathrm{X}-2,20-21 \mathrm{~cm}$ & 146.3 & 0 & 0 & 0 & 0 & 0 & 0 & 1000 & 0 \\
\hline $16 \mathrm{X}-2,25-27 \mathrm{~cm}$ & 146.4 & 341 & 636 & 341 & 0 & 136 & 227 & 0 & 136 \\
\hline $16 \mathrm{X}-2,29-30 \mathrm{~cm}$ & 146.4 & 379 & 397 & 379 & 121 & 224 & 431 & 103 & 172 \\
\hline $16 \mathrm{X}-2,43-44 \mathrm{~cm}$ & 146.5 & 588 & 644 & 613 & 464 & 608 & 448 & 402 & 180 \\
\hline $16 \mathrm{X}-2,48-49 \mathrm{~cm}$ & 146.6 & 1140 & 1249 & 1264 & 399 & 850 & 1269 & 637 & 368 \\
\hline $16 X-2,60-61 \mathrm{~cm}$ & 146.7 & 706 & 686 & 758 & 314 & 546 & 799 & 479 & 227 \\
\hline $16 \mathrm{X}-2,69-70 \mathrm{~cm}$ & 146.8 & 646 & 699 & 684 & 330 & 466 & 709 & 539 & 194 \\
\hline \multicolumn{10}{|l|}{ 722B- } \\
\hline $29-3,140-141 \mathrm{~cm}$ & 270.3 & 516 & 382 & 373 & 41 & 157 & 415 & 230 & 92 \\
\hline $29 \mathrm{X}-3,130-131 \mathrm{~cm}$ & 270.2 & 777 & 1045 & 1094 & 424 & 732 & 1147 & 612 & 424 \\
\hline $29 \mathrm{X}-4,20-21 \mathrm{~cm}$ & 270.6 & 764 & 418 & 845 & 473 & 109 & 527 & 173 & 273 \\
\hline $29 \mathrm{X}-4,60-61 \mathrm{~cm}$ & 271.0 & 296 & 74 & 222 & 0 & 0 & 185 & 0 & 37 \\
\hline
\end{tabular}


Table 3 (continued),

\begin{tabular}{|c|c|c|c|c|c|c|c|c|c|}
\hline Sample & $\begin{array}{l}\text { Depth } \\
\text { (mbsf) }\end{array}$ & $\begin{array}{c}\text { Phytane } \\
(\mu \mathrm{g} / \mathrm{g} \text { TOC })\end{array}$ & $\begin{array}{c}\text { Dimethyl- } \\
\text { pyrrole } \\
\text { ( } \mu \mathrm{g} / \mathrm{g} \text { TOC) }\end{array}$ & $\begin{array}{c}\text { Trimethyl } \\
\text { thiophene } \\
(\mu \mathrm{g} / \mathrm{g} \text { TOC) }\end{array}$ & $\begin{array}{c}\text { Methyl- } \\
\text { phenole } \\
(\mu \mathrm{g} / \mathrm{g} \text { TOC) }\end{array}$ & $\begin{array}{c}\text { Dimethyl } \\
\text { thiophene } \\
(\mu \mathrm{g} / \mathrm{g} \text { TOC) }\end{array}$ & $\begin{array}{c}\text { Xylene } \\
(\mu \mathrm{g} / \mathrm{g} \text { TOC })\end{array}$ & $\begin{array}{c}\text { Ethyl-methyl } \\
\text { benzene } \\
\text { ( } \mu \mathrm{g} / \mathrm{g} \text { TOC) }\end{array}$ & $\begin{array}{l}\text { Naphthalene } \\
(\mu \mathrm{g} / \mathrm{g} \text { TOC) }\end{array}$ \\
\hline RC2709 & 0.0 & 65 & 888 & 388 & 700 & 0 & 2682 & 658 & 923 \\
\hline $\mathrm{RC} 2712$ & 0.0 & 58 & 650 & 114 & 572 & 0 & 1486 & 561 & 718 \\
\hline $\mathrm{RC} 2714$ & 0.0 & 98 & 353 & 483 & 664 & 0 & 2515 & 889 & 968 \\
\hline $\mathrm{RC} 2723$ & 0.0 & 81 & 385 & 153 & 371 & 0 & 1026 & 691 & 509 \\
\hline $\mathrm{RC} 2724$ & 0.0 & 30 & 163 & 81 & 289 & 0 & 811 & 248 & 226 \\
\hline \multicolumn{10}{|l|}{$723 \mathrm{~A}-$} \\
\hline $1 \mathrm{H}-4,144-145 \mathrm{~cm}$ & 5.9 & 61 & 1278 & 933 & 872 & 0 & 5228 & 1622 & 889 \\
\hline $1 \mathrm{H}-4,145-150 \mathrm{~cm}$ & 5.9 & 78 & 478 & 94 & 561 & 0 & 4011 & 1156 & 517 \\
\hline $2 \mathrm{H}-3,149-150 \mathrm{~cm}$ & 14.1 & 60 & 686 & 143 & 369 & 0 & 1346 & 766 & 203 \\
\hline $3 \mathrm{H}-4,144-145 \mathrm{~cm}$ & 23.4 & 85 & 1028 & 1099 & 394 & 704 & 5507 & 1789 & 831 \\
\hline $6 \mathrm{H}-4,144-145 \mathrm{~cm}$ & 52.3 & 113 & 809 & 500 & 353 & 838 & 4289 & 1662 & 588 \\
\hline $7 \mathrm{H}-2,149-150 \mathrm{~cm}$ & 65.5 & 84 & 838 & 1318 & 433 & 1031 & 4491 & 624 & 307 \\
\hline $9 \mathrm{H}-4,144-145 \mathrm{~cm}$ & 87.7 & 145 & 1165 & 996 & 764 & 822 & 3701 & 1467 & 864 \\
\hline $11 X-1,149-150 \mathrm{~cm}$ & 96.3 & 55 & 1318 & 764 & 409 & 927 & 3800 & 2200 & 445 \\
\hline $13 \mathrm{X}-4,149-150 \mathrm{~cm}$ & 119.8 & 111 & 380 & 360 & 517 & 689 & 5086 & 1440 & 500 \\
\hline $16 \mathrm{X}-2,149-150 \mathrm{~cm}$ & 142.1 & 61 & 482 & 321 & 179 & 554 & 2679 & 1200 & 286 \\
\hline $18 X-5,0-1 \mathrm{~cm}$ & 164.6 & 107 & 699 & 418 & 678 & 0 & 3579 & 1257 & 287 \\
\hline $20 \mathrm{X}-4,0-5 \mathrm{~cm}$ & 186.3 & 208 & 1127 & 554 & 742 & 942 & 5223 & 2042 & 500 \\
\hline $24 X-3,0-1 \mathrm{~cm}$ & 223.4 & 107 & 736 & 1096 & 644 & 1736 & 6331 & 3287 & 1096 \\
\hline $26 \times-3,0-1 \mathrm{~cm}$ & 242.8 & 129 & 1116 & 816 & 725 & 1225 & 5766 & 2714 & 566 \\
\hline $29 \mathrm{X}-6,119-120 \mathrm{~cm}$ & 277.4 & 77 & 432 & 923 & 1195 & 1298 & 6184 & 5070 & 823 \\
\hline $36 \mathrm{X}-5,145-150 \mathrm{~cm}$ & 333.6 & 231 & 1321 & 1717 & 507 & 1372 & 13262 & 4862 & 672 \\
\hline $38 \mathrm{X}-5,145-150 \mathrm{~cm}$ & 380.0 & 70 & 595 & 827 & 264 & 568 & 3976 & 2516 & 456 \\
\hline $41 X-2,0-1 \mathrm{~cm}$ & 410.0 & 93 & 791 & 655 & 755 & 724 & 3704 & 2476 & 620 \\
\hline \multicolumn{10}{|l|}{$728 \mathrm{~A}-$} \\
\hline $3 \mathrm{H}-4,119-120 \mathrm{~cm}$ & 21.4 & 0 & 981 & 625 & 413 & 394 & 1817 & 1423 & 692 \\
\hline $6 \mathrm{H}-4,119-120 \mathrm{~cm}$ & 53.9 & 53 & 612 & 432 & 344 & 573 & 2181 & 1203 & 326 \\
\hline $9 \mathrm{H}-4,119-120 \mathrm{~cm}$ & 81.8 & 64 & 1048 & 700 & 881 & 1247 & 3398 & 2247 & 461 \\
\hline $12 \mathrm{X}-2,119-120 \mathrm{~cm}$ & 107.6 & 102 & 512 & 749 & 641 & 1014 & 3586 & 1661 & 508 \\
\hline $15 X-4,119-120 \mathrm{~cm}$ & 139.6 & 94 & 326 & 518 & 606 & 700 & 2612 & 1482 & 474 \\
\hline $18 \mathrm{X}-4,119-120 \mathrm{~cm}$ & 168.5 & 101 & 417 & 728 & 884 & 888 & 3819 & 1591 & 942 \\
\hline $21 X-5,0-1 \mathrm{~cm}$ & 197.8 & 122 & 174 & 550 & 460 & 640 & 2698 & 1035 & 376 \\
\hline \multicolumn{10}{|l|}{$722 \mathrm{~A}-$} \\
\hline $16 \mathrm{X}-2,20-21 \mathrm{~cm}$ & 146.3 & 0 & 0 & 2000 & 2000 & 5500 & 12500 & 4500 & 4500 \\
\hline $16 \mathrm{X}-2,25-27 \mathrm{~cm}$ & 146.4 & 0 & 0 & 886 & 818 & 1477 & 3545 & 1182 & 864 \\
\hline $16 \mathrm{X}-2,29-30 \mathrm{~cm}$ & 146.4 & 86 & 310 & 586 & 776 & 1138 & 5793 & 1293 & 845 \\
\hline $16 \mathrm{X}-2,43-44 \mathrm{~cm}$ & 146.5 & 98 & 778 & 840 & 830 & 1072 & 4232 & 1598 & 789 \\
\hline $16 \times-2,48-49 \mathrm{~cm}$ & 146.6 & 238 & 1544 & 834 & 1016 & 902 & 7415 & & 1026 \\
\hline $16 \mathrm{X}-2,60-61 \mathrm{~cm}$ & 146.7 & 155 & 1253 & 479 & 789 & 933 & 5454 & 1552 & 686 \\
\hline $16 \mathrm{X}-2,69-70 \mathrm{~cm}$ & 146.8 & 150 & 1612 & 971 & 850 & 830 & 3228 & 1466 & 796 \\
\hline \multicolumn{10}{|l|}{ 722B- } \\
\hline $29-3,140-141 \mathrm{~cm}$ & 270.3 & 37 & 129 & 203 & 364 & 728 & 2922 & 1300 & 433 \\
\hline $29 \mathrm{X}-3,130-131 \mathrm{~cm}$ & 270.2 & 330 & 1902 & 853 & 759 & 1317 & 3616 & 2067 & 754 \\
\hline $29 \mathrm{X}-4,20-21 \mathrm{~cm}$ & 270.6 & 145 & 0 & 0 & 791 & 1027 & 3036 & & 964 \\
\hline $29 \times-4,60-61 \mathrm{~cm}$ & 271.0 & 37 & 222 & 778 & 704 & 963 & 6000 & 1222 & 1148 \\
\hline
\end{tabular}


Table 3 (continued).

\begin{tabular}{|c|c|c|c|c|c|c|c|c|}
\hline Sample & $\begin{array}{l}\text { Depth } \\
\text { (mbsf) }\end{array}$ & $\begin{array}{l}\text { Methylfuran } \\
(\mu \mathrm{g} / \mathrm{g} \text { TOC })\end{array}$ & $\begin{array}{c}\text { Methyl- } \\
\text { naphthalene } \\
(\mu \mathrm{g} / \mathrm{g} \text { TOC) }\end{array}$ & $\begin{array}{c}\text { Benzo- } \\
\text { thiophene } \\
(\mu \mathrm{g} / \mathrm{g} \text { TOC) }\end{array}$ & $\begin{array}{c}\text { Sum } \\
\text { (mg/g TOC) }\end{array}$ & $\begin{array}{l}\text { Score on } \\
\text { Factor } 1\end{array}$ & $\begin{array}{l}\text { Score on } \\
\text { Factor } 2\end{array}$ & $\begin{array}{l}\text { Score on } \\
\text { Factor } 3\end{array}$ \\
\hline RC2709 & 0.0 & 814 & 535 & 0 & 17.42 & -0.598 & -0.565 & -0.507 \\
\hline $\mathrm{RC} 2712$ & 0.0 & 1719 & 497 & 0 & 13.78 & -0.843 & -0.547 & -0.735 \\
\hline $\mathrm{RC} 2714$ & 0.0 & 991 & 381 & 211 & 16.28 & -0.596 & -0.602 & -0.443 \\
\hline $\mathrm{RC} 2723$ & 0.0 & 83 & 409 & 175 & 11.52 & -0.999 & -0.42 & -0.37 \\
\hline RC2724 & 0.0 & 174 & 270 & 0 & 8.17 & -1.000 & -0.837 & -0.872 \\
\hline \multicolumn{9}{|l|}{$723 \mathrm{~A}-$} \\
\hline $1 \mathrm{H}-4,144-145 \mathrm{~cm}$ & 5.9 & 144 & 750 & 417 & 27.52 & 0.003 & -0.286 & -0.523 \\
\hline $1 \mathrm{H}-4,145-150 \mathrm{~cm}$ & 5.9 & 244 & 567 & 0 & 18.26 & -0.663 & -0.418 & -0.345 \\
\hline $2 \mathrm{H}-3,149-150 \mathrm{~cm}$ & 14.1 & 143 & 311 & 266 & 9.67 & -1.044 & -0.982 & -0.474 \\
\hline $3 \mathrm{H}-4,144-145 \mathrm{~cm}$ & 23.4 & 380 & 704 & 366 & 25.62 & -0.255 & -0.678 & 0.258 \\
\hline $6 \mathrm{H}-4,144-145 \mathrm{~cm}$ & 52.3 & 0 & 873 & 770 & 28.80 & -0.005 & -0.02 & 0.135 \\
\hline $7 \mathrm{H}-2,149-150 \mathrm{~cm}$ & 65.5 & 296 & 940 & 389 & 27.25 & -0.296 & 0.174 & 0.542 \\
\hline $9 \mathrm{H}-4,144-145 \mathrm{~cm}$ & 87.7 & 2897 & 864 & 719 & 31.87 & -0.051 & 0.385 & 0.133 \\
\hline $11 X-1,149-150 \mathrm{~cm}$ & 96.3 & 273 & 655 & 582 & 20.23 & -0.547 & -1.096 & 0.333 \\
\hline $13 \mathrm{X}-4,149-150 \mathrm{~cm}$ & 119.8 & 923 & 660 & 320 & 25.30 & -0.362 & -0.139 & 0.262 \\
\hline $16 \mathrm{X}-2,149-150 \mathrm{~cm}$ & 142.1 & 568 & 461 & 400 & 15.23 & -0.805 & -0.955 & -0.078 \\
\hline $18 X-5,0-1 \mathrm{~cm}$ & 164.6 & 1460 & 624 & 343 & 18.87 & -0.752 & -0.537 & -0.018 \\
\hline $20 \mathrm{X}-4,0-5 \mathrm{~cm}$ & 186.3 & 2231 & 1154 & 638 & 34.28 & 0.040 & 0.424 & 0.211 \\
\hline $24 X-3,0-1 \mathrm{~cm}$ & 223.4 & 616 & 1173 & 489 & 38.50 & 0.109 & 0.671 & 1.42 \\
\hline $26 \mathrm{X}-3,0-1 \mathrm{~cm}$ & 242.8 & 305 & 1536 & 659 & 36.36 & 0.032 & 0.812 & 1.077 \\
\hline $29 \mathrm{X}-6,119-120 \mathrm{~cm}$ & 277.4 & 959 & 1127 & 489 & 42.02 & -0.041 & 1.063 & 2.627 \\
\hline $36 \mathrm{X}-5,145-150 \mathrm{~cm}$ & 333.6 & 1210 & 1797 & 928 & 52.29 & 0.146 & 0.246 & 4.105 \\
\hline $38 \mathrm{X}-5,145-150 \mathrm{~cm}$ & 380.0 & 1566 & 772 & 566 & 28.56 & -0.365 & -0.043 & 0.746 \\
\hline $41 X-2,0-1 \mathrm{~cm}$ & 410.0 & 422 & 713 & 371 & 29.10 & -0.377 & 0.83 & 0.878 \\
\hline \multicolumn{9}{|l|}{$728 \mathrm{~A}-$} \\
\hline $3 \mathrm{H}-4,119-120 \mathrm{~cm}$ & 21.4 & - & 721 & 231 & 17.16 & -0.229 & -1.374 & -0.512 \\
\hline $6 \mathrm{H}-4,119-120 \mathrm{~cm}$ & 53.9 & - & 511 & 251 & 17.43 & -0.509 & -0.607 & -0.365 \\
\hline $9 \mathrm{H}-4,119-120 \mathrm{~cm}$ & 81.8 & - & 853 & 414 & 28.13 & 0.008 & 0.051 & 0.293 \\
\hline $12 \mathrm{X}-2,119-120 \mathrm{~cm}$ & 107.6 & - & 637 & 359 & 22.30 & -0.349 & -0.377 & 0.099 \\
\hline $15 X-4,119-120 \mathrm{~cm}$ & 139.6 & - & 579 & 247 & 20.14 & -0.616 & -0.188 & 0.326 \\
\hline $18 \mathrm{X}-4,119-120 \mathrm{~cm}$ & 168.5 & - & 710 & 467 & 29.14 & 0.033 & 0.549 & 0.142 \\
\hline $21 X-5,0-1 \mathrm{~cm}$ & 197.8 & - & 582 & 296 & 20.14 & -0.356 & 0.046 & -0.623 \\
\hline \multicolumn{9}{|l|}{$722 \mathrm{~A}$ - } \\
\hline $16 \mathrm{X}-2,20-21 \mathrm{~cm}$ & 146.3 & 0 & 3500 & 2500 & 79.00 & 5.233 & -2.563 & 0.453 \\
\hline $16 \mathrm{X}-2,25-27 \mathrm{~cm}$ & 146.4 & 0 & 1341 & 545 & 28.64 & 0.695 & -0.092 & -0.842 \\
\hline $16 \mathrm{X}-2,29-30 \mathrm{~cm}$ & 146.4 & 0 & 1138 & 603 & 30.00 & 0.511 & -0.141 & -0.758 \\
\hline $16 \times-2,43-44 \mathrm{~cm}$ & 146.5 & 0 & 1119 & 639 & 34.91 & 0.665 & 0.667 & -0.482 \\
\hline $16 \mathrm{X}-2,48-49 \mathrm{~cm}$ & 146.6 & & 1306 & 819 & 45.03 & 0.946 & 3.288 & -1.211 \\
\hline $16 \mathrm{X}-2,60-61 \mathrm{~cm}$ & 146.7 & 0 & 897 & 727 & 36.04 & 0.512 & 1.213 & -0.64 \\
\hline $16 \mathrm{X}-2,69-70 \mathrm{~cm}$ & 146.8 & 0 & 1432 & 597 & 36.74 & 0.825 & 1.021 & -0.802 \\
\hline \multicolumn{9}{|l|}{$722 \mathrm{~B}-$} \\
\hline $29-3,140-141 \mathrm{~cm}$ & 270.3 & 0 & 571 & 355 & 21.41 & -0.102 & -0.14 & -0.724 \\
\hline $29 \mathrm{X}-3,130-131 \mathrm{~cm}$ & 270.2 & 0 & 1388 & 643 & 40.92 & 0.673 & 2.312 & -0.864 \\
\hline $29 X-4,20-21 \mathrm{~cm}$ & 270.6 & & 1655 & 991 & 31.90 & 1.011 & 0.979 & -1.362 \\
\hline $29 X-4,60-61 \mathrm{~cm}$ & 271.0 & 0 & 1074 & 704 & 25.18 & 0.315 & -1.124 & -0.489 \\
\hline
\end{tabular}

